\title{
Path Dependence in the Law: The Course and Pattern of Legal Change in a Common Law System
}

\author{
Oona A. H athaway \\ I. PATH DEPENDENCE THEORY \\ A. INCREASING RETURNS PATH DEPENDENCE. \\ B. EVOLUtionary Path DEPENDENCE..... \\ C. Sequencing Path Dependence \\ II. The Path Dependence Of THE Common LAW SYSTEM \\ A. INCREASING RETURNS PATH DEPENDENCE. \\ B. EVOLUTIONARY PATH DEPENDENCE. \\ C. Sequencing Path Dependence.
}

III. CONSEQUENCES OF PATH DEPENDENCE THEORY FOR THE DOCTRINE OF STARE DECISIS
A. Cases in AReas of the LaW in Which Thereare FeW PUNCTUATIONS
B. CASES IN WHICH UNDERLYING CONDITIONS HAVE CHANGED MARKEDLY
C. CASESTHAT RELY ON DICTA

IV. CONCLUSION.

* Associate Professor of Law, Boston University School of Law. B.A., H arvard University; J.D., Yale Law School. I am grateful to Arthur Applbaum, Jack Beermann, Robert Bone, Chris Brooke, Ward Farnsworth, Alan Feld, Keith Hylton, David Kennedy, Susan Koniak, Gary Lawson, Mattias Kumm, Soeren Mattke, Steve Marks, Michael Meurer, Mark Pettit, Susan RoseAckerman, David J. Seipp, R. Justin Smith, Nancy Staudt, Sharon Street, Eli Wald, Larry Yackle, and other members of the faculty of Boston U niversity School of Law for their comments and suggestions on earlier drafts of this work. I am also grateful to Paul A. David for providing me with copies of some of his most recent unpublished works on path dependence theory. Jacob S. $\mathrm{H}$ acker deserves special thanks for his contributions at every stage of this project. 
[I]f we want to know why a rule of law has taken its particular shape, and more or less if we want to know why it eists at all, we go to tradition. We follow it into the Year Books, and perhaps beyond them to the customs of the Salian Franks, and somewhere in the past, in the German forests, in the needs of Norman kings, in the assumptions of a dominant class, in the absence of gen eralized ideas, we find out the practical motive for what now best is justified by the mere fact of its acceptance and that men are accu stomed to it. ${ }^{1}$

In a system of law that adheres to the doctrine of stare decisis, ${ }^{2}$ it is impossible to understand the law as it is today without understanding the law as it has been in the past. Reliance upon binding precedents leads courts to begin every new case with an examination of the past. The resolutions that arise in turn form a foundation for future cases. The doctrine of stare decisis thus creates a seamless web connecting the past to the present and future.

Legal scholars have long grappled with the role of history in the law. They have debated the importance of tradition in constitutional interpretation, ${ }^{3}$ the role of historical narrative in decision making, ${ }^{4}$ and the

1. Oliver Wendell Holmes, The Path of the Law, in Collected Legal Papers 167, 186 (1920) [hereinafter HOLMES, The Path of the Law].

2. The term stare decisis is derived from the phrase stare decisis et non quieta movere- "let the decision stand and do not disturb things which have been settled." John Paul Stevens, The Life Span of a Judge-M ade Rule, 58 N.Y.U. L. REV. 1, 1 n.2 (1983); seealso BLACK'S LAW DICTIONARY 1406 ( 6th ed. 1990) (defining stare decisis as "to abide by or adhere to decided cases"). In this Article, I use the term to refer to what is sometimes called as "vertical stare decisis" or the "doctrine of hierarchical precedent," under which the decisions of higher courts are binding on lower courts. Se Evan H. Caminker, Why M ust Inferior Courts 0 bey Superior Court Precedents?, 46 StAN. L. ReV. 817, 820-23 (1994) (describing and defending what Caminker terms the "doctrine of hierarchical precedent"); Michael C. Dorf, Dicta and ArticlellI, 142 U. PA. L. REV. 1997, 202425 (1994) (describing "vertical stare decisis"); Mark Alan Thurmon, When the Court Divides: Reconsidering the Precedential Value of Supreme Court Plurality Decisions, 42 DUKE L.J. 419, 436-37 (1992) (describing the distinction between "horizontal" and "vertical" stare decisis).

3. Some recent examples of work on the role of tradition in constitutional interpretation include 1 Bruce Ackerman, We the People: Foundations (1991); John Hart Ely, DEMOCRACY AND DISTRUST: A THEORY OF JUdICIAL REVIEW (1980); A MATTER OF Interpretation : Federal Courts ANd the LaW (Amy Gutmann ed., 1977); Rebecca L. Brown, Tradition and Insight, 103 YALE L.J. 177 (1993); John Hart Ely, Foreword: On Discovering Fundamental Values, 92 HARV. L. REV. 5 (1978); Lawrence Lessig, Fidelity and Constraint, 65 FORDHAM L. REV. 1365 (1997); Lawrence Lessig, Understanding Changed Readings: Fidelity and Theory, 47 StAN. L. REV. 395 ( 1995); David Luban, Legal Traditionalism, 43 STAN. L. REV. 1035 (1991); Roscoe Pound, The Theory of Judicial Decision, 36 HARV. L. REV. 641 (1923); A.C. Pritchard \& Todd J. Zywicki, Finding the Constitution: An Economic Analysis of Tradition's Role in Constitutional Interpretation, 77 N.C. L. REV. 409 (1999).

4. Recent work in this vein includes 1 ACKerman, supra note 3; AKHIL ReEd AmAR, The Bill of Rights: CReation and Reconstruction (1998); JoyCe ApPleby et al., Telling the Truth About history (1994); ERIC Foner, The Story of American Freedom (1998); William E. Forbath, LaW ANd the Shaping OF THe American Labor M OVement (1991); and Rogers M. SMith, CiviC IDEALS: Conflicting Visions of CITIZENSHIP IN U .S. History (1997). Several scholars have focused in particular on the role of historical narrative in the courts. See, 
value of precedent. ${ }^{5} \mathrm{~A}$ central strand of this scholarship has proposed and developed a theory that might be termed "legal evolution." ${ }^{16}$ This school of thought-which originated in the German "historical school" of jurisprudence in the nineteenth century and the flurry of related scholarship that followed the publication of Charles Darwin's $0 n$ the Origin of Species by $M$ eans of $N$ atural Selection ${ }^{7}$ - came to the center of analysis of legal doctrine with the work of Oliver Wendell Holmes in the $1880 \mathrm{~s}^{8} \mathrm{Holmes}^{\prime}$ work, in turn, set the stage for the law and economics school's more recent "evolution-to-efficiency" model of the common law. ${ }^{9}$

Despite the long recognition that history plays an important role in legal development, we still know surprisingly little about the specific ways in which history shapes the law. In this Article, I seek to fill this gap. I offer a set of analytic tools developed in the social sciences and evolutionary biologywhich I group together under the rubric of "path dependence theory" - to explore the influence of history in our common law system. ${ }^{10}$ In broad

e.g., W. LANCE Bennett \& Martha S. FELdman, ReConstru Cting REALity in the COURTRoom: JUSTICE AND JUDGMENT IN AMERICAN CULTURE 4 (1981) (discussing the role of narrative in trials); Robert M. Cover, The Su preme Court 1982 Term - Foreword: Nomos and Narrative, 97 H ARV. L. REV. 4, 45 (1983) ("No set of legal institutions or prescriptions exists apart from the narratives that locate it and give it meaning.... Once understood in the context of the narratives that give it meaning, law becomes not merely a system of rules to be observed, but a world in which we live."); Paul Gewirtz, Victims and Voyeurs at the Criminal Trial, 90 Nw. U. L. REV. 863, 864 (1996) ("[N]arrative and storytelling pervade the law, from the competing narratives in trial court proceedings to the legal and historical narratives appearing in Supreme Court opinions.").

5. There are two primary sets of arguments in favor of the doctrine of stare decisis: instrumental and intrinsic. For a description and examples of these claims, see infra notes 193202 and accompanying text. Other works debating the value of precedent include William N. Eskridge, Jr., O verruling Statutory Precedents, 76 GE O. L.J . 1361 (1988); Rafael Gely, Of Sinking and Escalating: A (Somewhat) New Look at Stare Decisis, 60 U. PITT. L. REV. 89 (1998); Jeffrie G. M urphy, Justifying Departures from Equal T reatment, $81 \mathrm{~J}$. PHIL. 587 (1984); Roscoe Pound, What of Stare Decisis?, 10 Fordham L. Rev. 1 (1941); James C. Rehnquist, The Power That Shall Be Vested in a Precedent: Stare Decisis, the Constitution and the SupremeCourt, 66 B.U. L. REV. 345 ( 1986).

6. For a comprehensive review of the history of the legal evolution literature, see $\mathrm{E}$. Donald Elliott, The Evolutionary Tradition in Jurisprudence, 85 CoLuM. L. REV. 38 (1985) [hereinafter Elliott, Evolutionary Tradition]. Se generally E. Donald Elliott, Law and Biology: The New Synthesis?, 41 ST. LouIS U. L.J. 595 (1997) (reviewing and critiquing a decade of developments in the use of biological metaphors in law); M.B.W. Sinclair, Evolution in Law: Second Thoughts, 71 U. Det. Mercy L. ReV. 31 (1993) (providing a critical review of the use of evolutionary theory in the law).

7. Charles Darwin, On the Origin of Species by Means of Natural Selection (J.W. Burrow ed., Penguin Books 1985) (1859); see also infra text accompanying notes 136-43 (discussing the history of evolutionary theory in legal scholarship).

8. See generally Oliver Wendell HOLMES, The COMmON LAW 1 (1881) [hereinafter HOLMES, THE COMMON LAW].

9. Se infra text accompanying notes $144-51$ (discussing modern law and economics model of legal evolution toefficiency).

10. Here I use the term "common law system" to refer to the common law legal tradition that traces to the English system, as opposed to the "civil law" or "socialist law" systems that form 
terms, "path dependence" means that an outcome or decision is shaped in specific and systematic ways by the historical path leading to it. It entails, in other words, a causal relationship between stages in a temporal sequence, with each stage strongly influencing the direction of the following stage. At the most basic level, therefore, path dependence implies that "what happened at an earlier point in time will affect the possible outcomes of a sequence of events occurring at a later point in time."11

Path dependence, as I use the term here, is not simply a restatement of the evolutionary model of law or a mere claim that "history matters." Rather, it consists of specific descriptions and explanations of how history influences the process of legal change in a common law system. In this Article, I identify three strands of path dependence theory, which I term "increasing returns path dependence," "evolutionary path dependence," and "sequencing path dependence." I then outline the characteristics of the common law system that lead to each type of path dependence and explore the implications of each for the course and pattern of change in the American common law system. In short, I explain how the path of the law shapes the law. ${ }^{12}$

the other two major legal traditions within the Western legal tradition. Se MARY ANN GLENDON ET AL., COMPARATIVE LEgal TRADITIONS 14 (1985) (describing briefly the different legal systems).

11. William H. Sewell, Jr., Three T emporalities: Toward an Eventful Sociology, in THE HISTORIC TURN IN THE HUMAN SCIENCES $262-63$ (Terrence J. McDonald ed., 1996).

12. Of course, others have recognized the historically contingent nature of the common law system, and a few have even used the broad term "path dependence" to describe some aspects of it. See Paul A. David, Intellectual Property Institutions and the Panda's Thumb: Patents, Copyrights, and Trade Secrets in Economic Theory and History, in GLOBAL DIMENSIONS OF InTellectual Property Rights in SCIenCe And TeChnology 19 ( Mitchel B. Wallerstein et al. eds., 1993) (noting path-dependent tendencies of intellectual property institutions). Seegenerally HOLMES, The Path of the Law, supra note 1 (noting, though not in those terms, the tendency of the common law toward path dependence); Richard A. Posner, Path-Dependency, Pragmatism, and a Critique of H istory in Adjudication and Legal Scholarship, 67 U . CHI. L. REV. 573 (2000) (warning, following N ietzsche, that the wrong kind of historical study can be bad for "life," including law); Clayton P. Gillette, The Path Dependence of the Law (Nov. 3, 1999) (unpublished manuscript, on file with author) (pointing out and expanding upon the path dependence aspects of Holmes's argument in The Path of the Law). But se generally S. J. Liebowitz \& Stephen E. Margolis, Path Dependence, Lock-In, and H istory, 11 J.L. EcoN. \& ORG. 205 ( 1995) [hereinafter Liebowitz \& Margolis, Path Dependencel (critiquing path dependence as an analytical perspective). The form of path dependence noted by these scholars is primarily of the most general form-the insight that past events influence future ones-and does not bear the specific characteristics or yield the specific predictions that I discuss below. Indeed, this form of the theory "has the unfortunate consequence of not distinguishing path-dependent analysis from most other types of sociological explanation." James Mahoney, U ses of Path Dependence in H istorical Sociology 4 (Sept. 1999) (unpublished manuscript, on file with author). Thus far, no one has engaged in an in-depth analysis of the insights that can be gained by applying specific forms of path dependence theory to the common law. Instead, the application of path dependence theory in the legal literature has been limited largely to explanations of patterns of change in corporate structures and corporate governance. See generally Lucian Arye Bebchuk \& Mark J. Roe, A Theory of Path Dependence in Corporate O wnership and Governance, 52 STAN. L. REV. 
Applying path dependence theory to the law leads to both striking insights and troubling conclusions. It reveals, for example, that courts' early resolutions of legal issues can become locked-in and resistant to change. This inflexibility can lead to inefficiency when legal rules fail to respond to changing underlying conditions. Path dependence theory also indicates that final outcomes will be difficult to predict ex ante, because they are highly dependent upon early decisions, which are in turn difficult, if not impossible, to predict. The theory further suggests that the opportunities for significant legal change in a common law system are brief and intermittent, occurring during critical junctures when new legal issues arise or higher courts or legislatures intercede. Moreover, it leads to the unsettling conclusion that the order in which cases arrive in the courts can significantly affect the specific legal doctrine that ultimately results.

Path dependence theory thus has relevance for both legal scholarship and legal practice. It guides legal practitioners to concentrate their resources on altering the path of the law, and it provides a new basis for scholars to question and refine the doctrine of stare decisis, which creates the law's path-dependent character. Indeed, path dependence theory raises once again the question of when the doctrine of stare decisis should govern-when, that is, the deleterious consequences of the path dependence that stare decisis engenders might justify modifying or relaxing this central tenet of our legal system.

The Article proceeds in three parts. Part I provides an overview of path dependence theory. It outlines the theory and briefly describes three separate strands of the theory: increasing returns path dependence, evolutionary path dependence, and sequencing path dependence, which are rooted in the economics, biological, and rational choice theory literatures, respectively. Although each of these strands has specific and unique characteristics, they are linked by a central insight: In each, an outcome or decision is shaped in specific and systematic ways by the path leading to it.

Each of these strands of path dependence in turn has important implications for the course and pattern of change in the common law system. Accordingly, Part II applies path dependence theory to the common law. At the core of the common law system is the requirement that courts adhere to the body of principles and rules of action that derive their authority "solely from usages and customs of immemorial antiquity, or from the judgments and decrees of the courts recognizing, affirming, and enforcing such usages and customs." ${ }^{\text {"13 }}$ Under the doctrine of stare decisis, higher courts' previous decisions are controlling, courts give their own

127 (1999); Marcel Kahan \& Michael Klausnev, Path Dependence in Corporate Contracting, 74 WASH. U. L.Q. 347 (1996); Mark J. Roe, Chaos and Evolution in Law and Economics, 109 H ARV.L. REV. 641 (1996).

13. BLACK'S LAW Dictionary 276 ( 6th ed. 1990) (defining "common law"). 
decisions significant weight, and courts look to non-binding decisions for persuasive precedent. Consequently, although there is some flexibility in the system, precedent remains central to legal deliberation.

The doctrine of stare decisis thus creates an explicitly path-dependent process. Later decisions rely on, and are constrained by, earlier decisions. More important, the way in which history shapes legal outcomes corresponds to the three-fold division introduced in Part I. Because each legal decision increases the probability that the next will take a particular form, the common law exhibits increasing returns path dependence. Because the law changes through a process of punctuated yet historically constrained evolution, the common law exhibits evolutionary path dependence. And because the legal process involves sequential decision making in a process marked by competing alternatives and multiple actors, the common law exhibits sequencing path dependence. Therefore, just as biological and social processes are constrained by history, the law is firmly guided by the heavy hand of the past.

Finally, Part III turns from the descriptive to the normative. It analyzes the implications of path dependence theory for the doctrine of stare decisis Path dependence theory reveals that significant costs may arise out of the reliance on precedent in a common law system. The Article concludes with the claim that, all other things being equal, where the costs of path dependence are expected to be especially significant, courts should consider relaxing the doctrine of stare decisis. This prescription not only supports modifying existing practices of reliance upon precedent, but also provides a theoretical basis for some existing distinctions in the degree that judges rely on certain categories of precedent.

\section{PATH DEPEndence TheORY}

The broad rubric of "path dependence" has been used in a variety of contexts to describe separate, but related, phenomena. In this Article, I argue that there are in fact three strands of path dependence theory. Each has specific, identifiable characteristics and, as I describe in Part II, each has important implications for the course and pattern of change in our common law system.

The first variant of path dependence, increasing returns path dependence, grows out of the economics literature. ${ }^{14}$ Increasing returns

14. See Liebowitz \& Margolis, Path Dependence, supra note 12, at 205 (noting the origins of this variant of path dependence theory); Paul Pierson, Increasing Returns, Path Dependence and the Study of Politics 3-7 (Oct. 15, 1996) [hereinafter Pierson, Increasing Returns] ( unpublished paper, presented at the Center for European Studies, Harvard University) (on file with author) (discussing the origins of this variant of path dependence theory). A few scholars have sought to break what I term "increasing returns path dependence" into separate categories of claims. Se, eg., Liebowitz \& Margolis, Path Dependence, supra note 12, at 207 (separating out the claims of what they call first, second, and third degree path dependence); 
path dependence arises where there are economies of increasing returnsincreasing the productive input yields more than a proportionate increase in output. ${ }^{15}$ Path dependence occurs because once a court makes an initial decision, it is less costly to continue down that same path than it is to change to a different path. ${ }^{16}$

A second variant of path dependence, evolutionary path dependence, draws on biological theory. There are, in turn, two separate strands of evolutionary path dependence. The first relies on the Darwinian claim that differential reproductive success of individual organisms leads to the gradual and progressive evolution of species. ${ }^{17}$ The second relies on a newer theory of evolution that focuses on "punctuated equilibria." ${ }^{18}$ Under this theory, species change little during most of their existence. This stability is punctuated by periods of rapid adaptation. Thus, change occurs in fits and starts rather than in slow and steady gradual steps. ${ }^{19}$ Although the hypothesized pattern of change is different in the two forms of evolutionary path dependence, the key insight is the same: Evolution is directly constrained by history. The possibilities for today and tomorrow are determined by the evolutionary changes of the past.

A third and final variant of path dependence theory is sequencing path dependence. This variant draws primarily on rational choice theory. Sequencing path dependence leads to the striking conclusion that where there are three or more choosers and three or more alternative outcomes, the sequence in which alternatives are considered can decisively influence

Roe, supra note 12 , at 647-53 (dividing path dependence claims into "weak," "semi-strong," and "strong"); Pierson, Increasing Returns, supra, at 3 (breaking path dependence into what he calls "broad" and "narrow" path dependence theory).

15. See generally KenNeth J. ARrow \& F. J. HAHN, General COMPETITIVE ANALYSIS 57-58, 152-53 (1971) (discussing increasing returns, as opposed to diminishing returns ).

16. As Margaret Levi puts it:

Path dependence has to mean, if it is to mean anything, that once a country or region has started down a track, the costs of reversal are very high. There will be other choice points, but the entrenchments of certain institutional arrangements obstruct an easy reversal of the initial choice. Perhaps the better metaphor is a tree, rather than a path. From the same trunk, there are many different branches and smaller branches. Although it is possible to turn around or to clamber from one to the other-and essential if the chosen branch dies - the branch on which a climber begins is the one she tends to follow.

Margaret Levi, A Model, a M ethod, and a Map: Rational Choice in Comparative and $\mathrm{H}$ istorical Analysis, in Comparative Politics: Rationality, Culture, And Structure 28 (Mark Irving Lichbach ed., 1997).

17. DARWIN, supra note 7, at 130-72 (describing the process of natural selection).

18. See infra text accompanying notes $48-54$ (describing the theory of "punctuated equilibria").

19. See Niles Eldredge, Time Frames: The Rethinking of DarWinian Evolution and THE THEORY OF PUNCTUATED EQUILIBRIA 118-122 (1985) [hereinafter ELDREDGE, TIME FRAMES] (describing the emergence of the theory of punctuated equilibria). 
the outcome. Thus, the order in which the aternatives are considered-or the path by which they are selected-shapes the outcome.20

\section{A. INCREASING RETURNS PATH DEPENDENCE}

A variant of path dependence theory that uses the idea of increasing returns to explain persistent market imperfections emerged in the economics literature of the 1980s as part of a renewed wave of attention by scholars to increasing returns economics. ${ }^{21}$ Of course, the idea of increasing returns (also known as "decreasing cost conditions") was hardly new. Adam Smith emphasized increasing returns to explain specialization and economic growth in his seminal work, An Inquiry into the Nature and Causes of the Wealth of $\mathrm{N}$ ations. ${ }^{22}$ Similarly, in the mid-1800s, A.A. Cournot developed theories of

20. Path dependence theory bears some resemblance to "rational herding" or "information cascades" theory. In information cascades theory, positive feedback loops result from imperfect information and decisionmakers' consequent rational and strategic decisions to emulate the actions of others who have faced similar decisions. Eric Talley offers a persuasive critique of this theory as applied to the common law. See generally Eric Talley, Precedential Cascades: An Appraisal, 73 S. CAL. L. REv. 87 (1999). That critique is not, however, applicable to path dependence theory, as the feedback loops in information cascades and the three forms of path dependence outlined here derive from largely distinct sources. Se generally Abhijit V. Banerjee, A Simple M odel of H erd Behavior, 107 Q. J. ECON . 797 (1992) (describing and applying a theory of information cascades); Sushil Bikhchandani, David Hirchleifer, \& Ivo Welch, A Theory of Fads, Fashion, Custom, and Cultural Change as Informational Cascades, $100 \mathrm{~J}$. PoL. ECON. 992 (1992) (describing and applying a theory of information cascades); David Hirshleifer, TheBlind Leading the Blind, Social Influence, Fads, and Informational Cascades, in THE NEW ECONOMICS OF BEHAVIOR 188 (Mariano Tommasi \& Kathryn Ierulli eds., 1995) (same); Roger Larocca \& William McLauchlan, Informational Cascades in State Appellate Courts (Sept. 1, 2000) (unpublished paper, presented at the American Political Science Association) (on file with author) (using an information cascade model to explain patterns in state supreme court decision making).

21. International trade theorists, in particular, began to develop models of trade based on monopolistic competition-competition under conditions of increasing returns. Se generally AVINASH K. Dixit \& Victor NoRman, TheORY Of INTERnATIONAL TRADE: A DUAL, General EQUILIBRIUM APPROACH (1980) (describing a model of trade that incorporates and accounts for increasing returns); ELHANAN H ELPMAN \& PAUL R. KRUGMAN, M ARKET STRUCTURE AND FOREIGN TRADE: INCREASING RETURNS, IMPERFECT COMPETITION, AND THE INTERNATIONAL ECONOMY (1984) (same); Elhanan Helpman, Increasing Returns, I mperfect M arkets, and Trade Theory, in 1 H ANDBOOK OF I NTERNATIONAL E CONOMICS 325 (Ronald W. Jones \& Peter B. Kenen eds., 1984) (same); Paul Krugman, New Theories of Trade Among Industrial Countries, 73 AM. ECON. REV. 343 ( 1983) (same). For more on the international trade literature regarding increasing returns, see infra note 43 . The story of the growth of the literature surrounding increasing returns economics is still hotly contested. Se Paul Krugman, The L egend of Arthur: A T ale of Gullibility at The New Yorker, at http:/ / www.slate.com/ dismal/ 98-01-14/ dismal.asp (posted Jan. 14, 1998), and responses thereto at http:/ / slate.msn.com/ Features/ Krugman/ Krugman.asp (posted Jan. $30,1998)$. The reaction by Krugman and others appears to have been provoked in part by what they consider an inaccurate recounting of the rise of increasing returns economics in $W$. M ITCHELl WALDROP, COMPLEXITY (1992), and a similar story in The N ew Yorker, John Cassidy, The Force of an Idea, THE NEW YORKER, Jan. 12, 1998, at 32-37. The story recounted here includes only the elements of the story on which most scholars would agree.

22. Adam Smith, An Inquiry into the Nature and Causes of the Wealth of Nations 
monopoly and oligopoly to explain the effects of increasing returns ${ }^{23}$ And in the late 1800s, Alfred Marshall examined what he termed the "Law of Increasing Returns." 24 In the decades that followed, other scholars continued to explore the implications of increasing returns for imperfect competition..$^{25}$

In the economy, increasing returns arise primarily from four characteristics: large set up or fixed costs, which lead to falling unit costs as output increases; learning effects, which lower costs as a product becomes more common; coordination effects, which confer ben efits for taking action similar to others; and self-reinforcing or adaptive expectations, which lead actors to react to current conditions in ways that enhance the likelihood that similar conditions will persist in the future. ${ }^{26}$ In processes that exhibit these characteristics, a step in one direction decreases the cost (or increases the benefit) of an additional step in the same direction, creating a powerful cycle of self-reinforcing activity or positive feedback.

Increasing returns path-dependent processes have several identifiable properties. ${ }^{27}$ First, there is indeterminacy of outcome. Unlike in classical economics, in which decreasing returns lead to a single, predictable equilibrium, multiple equilibria are possible in increasing returns processes. ${ }^{28}$ The outcome of a process that exhibits increasing returns is therefore indeterminate and unpredictable ex ante. W. Brian Arthur, whose work is among the earliest to link increasing returns to path dependence theory, illustrates this quality by reference to a mathematical illustration termed the "Polya urn process." 29 The Polya urn is an urn that contains two

(1776)

23. Augustin A. Cournot, Researches into the mathematical Principles of the THEORY OF WEALTH 56-66 (Nathaniel T. Bacon trans., The Macmillan Co. 1927) (1838).

24. 1 Alfred MARShall, Principles Of Economics 319 (5th ed. 1907) (1890) (defining the "Law of Increasing Returns" as follows: "An increase of capital and labour leads generally to an improved organization... [which in turn] gives a return increased more than in proportion.").

25. For examples of such works, see W. BRIAN ARTHUR, INCREASING RETURNS AND PATH DEPENDENCE IN THE ECONOMY (1994); NICHOLAS KALDOR, ECONOMICS WITHOUT EQUILIBRIUM (1985); and J OAN ROBINSON, THE ECONOMICS OF IMPERFECT COMPETITION (1933).

26. See W. Brian Arthur, Self-Reinforcing M echanisms in Economics, in ARTHUR, supra note 25, at 112 [hereinafter Arthur, Self-Reinforcing M echanisms]. All four characteristics need not be present in order for there to be increasing returns. Sæid. at 112.

27. This typology borrows heavily from Arthur, Self-Reinforcing M echanisms, supra note 26; and W. Brian Arthur, Competing Technologies, Increasing Returns, and Lock-In by Historical Small Events, 99 ECON J. 116 (1989), reprinted in ARTHUR, supra note 25 [hereinafter Arthur, Competing Technologies]. Arthur adds a fourth property to the three listed here: "possible inefficiency." Arthur, Self-Reinforcing M echanisms, supra note 26 , at 113 . Because that property appears to be largely a consequence of two other properties-lock-in and nonergodicity-I do not treat it as a separate property. I agree, however, that possible inefficiency is an important consequence of increasing returns path dependence, as I discuss below.

28. See Arthur, Self-Reinforcing M echanisms, supra note 26, at 112.

29. The term gets its name from mathematician George Polya. For early works using the 
balls, one red and one white. The experimenter randomly chooses and removes one ball and returns it to the urn with a ball of the same color, repeating the process until the urn fills with balls. In this example, there is no way to predict in advance the final ratio of red to white balls for any individual trial. The most we can say is that the final ratio of balls is a random variable uniformly distributed between zero and one. ${ }^{30}$ Similarly, in markets that exhibit unlimited increasing returns economies, it is not possible to predict which firm will dominate the market based on firm attributes alone: Just as the outcome of the Polya urn process is heavily dependent on early draws, the final shape of a market that exhibits such increasing returns is heavily dependent on early events. ${ }^{31}$

Second, increasing returns processes often lead to lock-in or inflexibility. An example best illustrates this property. In the Polya urn experiment, the ratio in any individual trial will eventually reach an equilibrium or, in mathematical terms, approach a limit. Later draws in the series will not significantly alter the distribution of balls in the urn. ${ }^{32}$ Likewise, in markets involving activities that offer greater returns the more they are undertaken, the activity that is chosen first will be much more likely to be chosen thereafter. ${ }^{33}$ Markets involving new technologies provide a good example of this dynamic. ${ }^{34}$ An industry exploring a new engineering or economic possibility may consider several different technologies that could be used to realize that possibility. The industry will likely select the undeveloped technology that appears to offer a small advantage over the others. As it is developed, the technology gradually improves so that the industry increasingly prefers it to the undeveloped, unimproved technologies. The initially selected technology thus becomes locked in and will continue to be dominant even if it later becomes apparent that an equally developed alternative could have been superior. ${ }^{35}$ Rational expectations can play an important role in encouraging these lock-in effects.

Polya urn process to illustrate path dependence, see W. Brian Arthur et al., On Generalized Urn Schemes of the Polya Kind, 19 CyBERnetics 61 (1983); W. Brian Arthur et al., Strong Laws for a Class of Path-Dependent Urn Processes, in Proceedings OF THE INTERnational Conference on Stochastic O PTIMIZATION, KIEV (1985), reprinted in ARTHUR, supra note 25, at 185-201. The following example draws heavily from W. Brian Arthur et al., Path-Dependent Processes and the Emergence of M acrostructure, in ARTHUR, supra note 25, at 36-38 [hereinafter Arthur et al., Path Dependent Processes]; and Pierson, Increasing Returns, supra note 14, at 6.

30. See Arthur et al., Path-Dependent Processes, supra note 29, at 36.

31. See Arthur, Competing T echnologies, supra note27, at 116.

32. SeeArthur et al., Path -D ependent Processes, supra note 29, at 36.

33. Not all markets exhibiting increasing returns tend to lock-in monopoly outcomes. When there is con sumer heterogeneity, an increasing returns market can be shared. See, e.g., Arthur, Competing Technologies, supra note 27, at 25-26 (discussing examples of this market phenomenon).

34. Id. at 15-26; Arthur, Self-R enforcing M echanisms, supra note 26, at 116.

35. See Arthur, Self-Reinforcing M echanisms, supra note26, at 116. 
When a product is slightly better than then-existing alternatives, the increased probability that it will do well in the market will enhance expectations of its success. This can hasten the transition to a monopoly outcome. $^{36}$

Third, increasing returns processes tend toward nonergodicity, as small early events can significantly affect the eventual outcome. ${ }^{37}$ For instance, the final outcome of the Polya urn test depends strongly on the outcome of early, random draws. ${ }^{38}$ In an increasing returns industry, small events can gradually cumulate to lock the market into the monopoly of an inferior technology. Consequently, as an early article on increasing returns path dependence explains, "it is sometimes not possible to uncover the logic (or illogic) of the world around us except by understanding how it got that way." ${ }^{39}$

The development of the Q werty typewriter keyboard provides an oftcited example of the characteristics and consequences of increasing returns processes. ${ }^{40}$ According to Paul A. David, the Q werty keyboard's ascendance into dominance during the 1890s occurred largely because of the advent of touch typing. The early adaptation of touch typing to the Q werty keyboard led to significant learning costs, coordination effects, and self-reinforcing expectations that favored the keyboard arrangement. Typists had to invest significant time into learning a particular keyboard arrangement; therefore it was costly for typists who were familiar with one keyboard arrangement to learn a different one. Coordination effects emerged because the new typewriter system required technical interrelatedness between the keyboard and the touch typist's memory. As a result, the process possessed significant economies of scale: The larger the number of individuals familiar with a particular keyboard arrangement, the lower the overall user cost of a typewriter system based on that arrangement. Finally, self-reinforcing

36. See id. at 128. Seegen erally Joseph Farrell \& Garth Saloner, Standardization, Compatibility, and Innovation, 16 RAND. J. ECON. 70 (1985).

37. See Arthur, Competing T echnologies, supra note 27, at 14.

38. See Arthur et al., Path -D ependent Processes, supra note 29, at 38.

39. Paul A. David, Clio and theE conomics of QWERTY, 75 AM. E CON. REV. 332, 332 (1985).

40. The "Q werty keyboard" gets its name from its six upper left-hand keys. The top line of the Q werty keyboard was arranged at least in part to make it possible for salespersons to quickly and easily demonstrate the machine by quickly typing the name of the company that produced it-Typewriter. The details of this example derive directly from David, supra note 39 . Notably, the historical accuracy of the Q we rty example has been questioned. Se S.J. L iebowitz \& Stephen E. Margolis, The Fable of the Keys, 33 J.L. \& ECON . 1, 3 (1990) (arguing that the Q werty example given in Paul David's 1985 article is "an example of market failure that will not withstand the rigorous examination of the historical record"). David has written several unpublished papers in response to the critiques of the Q werty example, including, most notably, Paul A. David, At Last, a Remedy for Chronic QWERTY-Skepticism (Sept. 1999) (unpublished manuscript, on file with author) [hereinafter David, At Last, a Remedy]. Despite the debate over its accuracy, the example continues to be considered one of the early illustrations of path dependence theory's central insights. 
expectations further solidified the Q werty keyboard's dominance: Employers purchased Q werty keyboards because they expected more typists to be able to use them than the alternative available arrangements, and typists invested in learning the Q werty keyboard arrangement because they expected that more employers would supply it. Because of these strong learning, coordination, and self-reinforcing expectation effects, the Q werty keyboard's early dominance allowed it to become locked in as the dominant keyboard arrangement despite the apparent superiority of later-developed keyboard arrangements. Thus, the increasing returns characteristics of the typewriter keyboard process may have driven the industry into standardization of the "wrong system." 41

Scholars have used increasing returns path dependence to explain a wide array of other apparent failures of standard economic theory. For example, Paul Krugman and W. Brian Arthur both use the increasing returns variant of path dependence theory to explain the importance of history in determining industry location patterns. ${ }^{42}$ Some of the earliest work on increasing returns path dependence was done in the field of international political economy: The incorporation of increasing returns into trade theory required the modification of some of the central tenets of trade theory and helped solve some of its deepest puzzles. ${ }^{43}$ More recently,

41. See David, At Last, a Remedy, supra note 40, at 336 (stating that this "was a situation in which the precise details of timing in the development sequence had made it privately profitable in the short run to adopt machines to the habits of men").

42. As Krugman puts it in a 1991 article in which he uses path dependence theory to explain the persistence of the U.S. manufacturing belt, "[i]f there is one single area of economics in which path dependence is unmistakable, it is in economic geography-the location of production in space." Paul Krugman, History and Industry Location: The Case of the M anufacturing Belt, 81 AM. ECON. REV. 80, 80 (1991). Arthur also argues that the process of industry geography is highly path dependent, but he focuses instead on the more specific question of why particular industries tend to be geographically concentrated. The key factor to explaining the concentration of an industry, he finds, is whether the industry possesses economies of agglomeration, that is, whether firms in the industry receive increasing net benefits from locating near firms in the same industry as the number of firms in the same location increases. See W. Brian Arthur, In dustry L ocation Patterns and the Importance of $\mathrm{H}$ istory, in ARTHUR, supra note 25, at 49-67; see also W. Brian Arthur, Positive Feedback in the Econ omy, $262 \mathrm{SCI}$. AM. 92, 95 (1990) (arguing that "the ran dom historical sequence of firms entering the industry determines which pattern of regional settlement results").

43. For example, scholars used increasing returns to explain why trade between countries often failed to fit the predictions of the theory of comparative advantage. Se HELPMAN \& KRUGMAN, supra note 21, at 25, 205-09 (detailing the shortcomings of conventional trade theory, including its "apparent failure to explain the volume of trade, the composition of trade, the volume and role of intrafirm trade and direct foreign investment, and the welfare effects of trade liberalization," and arguing that where transportation costs are low, small differences in country size will lead increasing returns products to be produced in the country with the larger domestic market). For other international political economy works drawing $m$ increasing returns economics, see, for example, R.W. Jones \& J.P. Neary, ThePositiveT heory of International Trade, in INTERnATIONAL TRADE: SURVEYS OF TheORY AND POLICY 48-50 (Ronald W. Jones ed., 1986); and DIXIT \& NORMAN, supra note21, at 265-95. 
Douglass North used increasing returns path dependence to explain institutional emergence and change. ${ }^{44}$ And in recent years, scholars have paid significant new attention to the ways in which the increasing returns variant of path dependence can be used to explain broader political processes. $^{45}$

Despite their varied topics, these separate veins of scholarship share the same basic insight: Where a process of change exhibits increasing returns dynamics, each step in one direction makes additional steps in that same direction more likely. This characteristic leads to predictable results and helps explain why some processes of change fail to evolve toward a single, stable, efficient equilibrium. As we shall see in Part II, similar observations can be made regarding the pattern of legal change in a common law system.

\section{B. EVolutionary path Dependence}

A second variant of path dependence theory draws on analogies to

44. North explains that the institutional framework of a polity and economy-defined broadly as the rules and informal constraints, and their enforcement characteristics, that shape human interaction - is characterized by increasing returns. Consequently, incremental change is heavily weighted in favor of policies consistent with the existing institutional framework. As an organization evolves to capture the highest payoffs available under the existing framework, it gradually altersthe institutional constraints within which it operates in a way that reinforces the initial direction of its effort. Hence, the direction of the polity, like that of the economy, is difficult to reverse. See generally Douglass C. NORTH, INSTITUTIONS, INSTITUTIONAL CHANGe and Economic Performance 92-104 (1990); Douglass C. North, The Historical Evolution of Politics, 14 INT'L REV. L. \& ECON. 381 (1994); Douglass C. North, A Transaction Cost Theory of Politics, 2 J. THEORETICAL POL. 355, 36466 (1990) [hereinafter North, A Transaction Cost Theory].

45. Paul Pierson provides an insightful overview of the application of increasing returns path dependence to political science and suggests how its application to politics is both similar to and different from its application in economics. See Pierson, Increasing Returns, supra note 14; se generally Paul Pierson, The L imits of Institutional Design: Explaining Institutional O rigins and Change, GOVERNANCE (forthcoming 2000) (applying increasing returns path dependence theory to explain political processes); Paul Pierson, N ot Just What, but When: T iming and Sequence in Political Processes, STUd. AM. POL. DeV. (forthcoming 2000) (same); Paul Pierson, When Effect Becomes Cause, 45 WORLD POL. 595 (1993) (same). Pierson's work follows and draws upon, among others: Charles E. LINDBlom, Politics AND MARKETS: THE World'S POLITICALECONOMIC SYSTEMS 3 (1977) (examining the interaction between politics and economics); NORTH, supra note 44 (developing an analytical framework for explaining the ways in which institutions and institutional change affect economic development); Stephen D. Krasner, A pproaches to the State: Alternative Conceptions and Historical Dynamics, 16 COMP. POL. 223, 23438 (1984) (examining the interaction between institutions and their environment); Terry M. Moe, T he N ew Economics of Organization, 28 AM. J. PoL. SCI. 739 (1984) (providing an overview of the "new economics of organization" and exploring its implications for the study of public bureaucracy); Terry M. Moe, The Politics of Structural Choice: T oward a Theory of Public Bu reaucracy, in Organization Theory: From Chester Barnard to the Present and Beyond 116-53 (Oliver E. Williamson ed., 1995) (arguing that political science is fertile territory for "new economics of organization" theory, but noting that political scientists should explore the aspects of the theory that are unique to political science, rather than simply extend the economic theory to politics and sketching a new theory of public bureaucracy using the insights of new economics); North, A Transaction Cost Theory, supra note 44 (providing a transaction costs framework for unde rstanding political and economic institutions). 
biological evolution. In its classical form, the biological version of path dependence reflects the paradigm of Darwinian "survival of the fittest." A newer form of this version of evolutionary path dependence relies on a more recent (and controversial) evolutionary model that I call "new evolutionary theory." Under this model, evolution is not gradual or incremental, but instead is characterized by "punctuated equilibria": Iong periods of stability followed by short bursts of rapid change.

Classical evolutionary theory posits that evolution occurs primarily through slow and gradual divergence of forms. Natural variation in the population combined with competition for limited resources leads to natural selection: Some organisms will be more "fit" than others-better equipped to survive and thus to reproduce. ${ }^{46}$ The differential reproductive success of individual organisms in turn leads to the gradual and progressive evolution of species. ${ }^{47}$

New evolutionary theory, by contrast, claims that evolution is characterized by periods of stasis followed by sudden change. In a model that biologists Niles Eldredge and Stephen Jay Gould termed "punctuated equilibrium," ${ }^{88}$ species change relatively little during most of their

46. See DARWIN, su pra note 7, at 130-72 (describing the process of natural selection); NILES ELDREDGE, REINVENTING DARWIN 37-39 (1995) [hereinafter ELDREDGE, REINVENTING DARWIN] (discussing conceptions of "fitness").

47. A contemporary of Darwin's, Thomas Henry Huxley, cautioned Darwin not to rely so heavily on his claim that evolution must be gradual. H uxley wrote, "You have loaded yourself with an unnecessary difficulty in adopting 'Natura non facit saltum' so unreservedly." ELDREDGE, TIME FRAMES, supra note 19, at 27 (quoting an 1859 letter from H uxley to Darwin). Some scholars have contested the characterization of Darwin as advocating simple "phyletic gradualism." They point out that Darwin's theory does not in any way preclude periods of stasis followed by periods of rapid change and that there are many passages in $0 \mathrm{n}$ the 0 rigin of Species by $M$ eans of $\mathrm{N}$ atural Selection in which Darwin indicates that evolution may proceed at a variety of rates. Se, eg., Daniel C. DennetT, DarWin's Dangerous IDEA: Evolution and the Meaning OF LIFE 282-99 (1995); David Penny, Charles Darwin, Gradualism and Punctuated Equilibrium, 32 SYSTEMATIC Zoology 72, 72-74 (1983); F.H.T. Rhodes, Gradualism, Punctuated Equilibrium, and the Origin of the Species, 305 NATURE 269, $269-72$ (1983). But seeELDREDGE, REINVENTING DARWIN, supra note 46, at 64-78 (arguing that Darwin viewed evolution as slow and gradual); ELDREDGE, TIME FRAMES, supra note 19, at 27 (arguing that "Darwin was less a pluralist in these matters than some these days would have him").

48. The term was introduced to the scientific community in a groundbreaking article by Niles Eldredge and Stephen Jay Gould. Niles Eldredge \& Stephen Jay Gould, Punctuated Equilibria: An Alternative to Phyletic Gradualism, in M ODELS IN PALEOBIOLO GY 82-115 (Thomas).M. Schopf ed., 1972), reprinted in ELDREDGE, TIME FRAMES, supra note 19, at 193; seealso ELDREDGE, TIME FRAMES, supra note 19, at 119 (discussing origination of the "punctuated equilibria" concept). The theory of punctuated equilibria has been hotly contested since its introduction. See, e.g., RICHARD DAWKINS, RIVER OUT OF EDEN 11, 83-84 (1995) (arguing that, contrary to the theory of punctuated equlibria, a key feature of evolution is its gradualness); DENNETT, su pra note 47, at 282-99 (disputing elements of Eldredge and Gould's theory of punctuated equilibria, particularly the claim that it is distinctly different from classical Darwinism); ELDREDGE, REINVENTING DARWIN, supra note 46, at 93-104 (describing the emergence of the idea of pun ctuated equilibria and the reaction, particularly of paleontologists, to it); ELDREDGE, TIME FRAMES, supra note 19, at 92-97, 120-22 (same). The debate is complicated by the fact that 
existence. ${ }^{49}$ This stability is punctuated by periods during which new species rapidly branch off from a persisting parental stock in a process of "speciation." ${ }^{50}$ Evolution results from the occurrence of these punctuations and the differential survival of the species they produce. The process of speciation is usually sparked when "a small local population becomes isolated at the margin of the geographic range of its parent species." ${ }^{\prime 51}$ Under this theory, the local populations, termed "peripheral isolates," quickly differentiate from the parent species because of the rapid adaptation of the small population to a distinct local environment under conditions of genetic isolation. ${ }^{52}$ Under some circumstances, these peripheral isolates develop into a new species, incapable of reintegration into the parent species. ${ }^{53}$ Thus, under new evolutionary theory, change occurs primarily in fits and starts rather than in slow and steady gradual steps. ${ }^{54}$

In the punctuated equilibrium model, as in the increasing returns path dependence model, the ultimate outcome of a process of change is usually

Eldredge and Gould appear to have always held slightly different ideas of what constitute "punctuated equilibria" and, moreover, have modified their views of the theory since its first introduction. See DENNETT, supra note 47, at 283-84 (claiming that Gould has "several times changed his mind" about whether the theory of punctuated equilibria was a revolutionary refutation of Darwinian gradualism); ELDREDGE, TIME FRAMES, supra note 19, at 16 ("From the very beginning . . . Stephen Jay Gould and I have differed to some extent on the significance, the implications-and even, on occasion, some aspect of basic content-of 'punctuated equilibria.'"); id. (revealing Eldredge's current and past views of the theory of punct uated equilibria).

49. See Eldredge, Time Frames, supra note 19, at 15 ("Punctuated equilibria still strikes me as an exceedingly simple idea: at base, it says that once a species evolves, it will usually not undergo great change as it continues its existence.").

50. Stephen Jay Gould, The Panda's Thumb 182 (1982) [hereinafter Gould, The PANDA'STHUMB].

51. Eldredge $\&$ Gould, supra note 48 , at 203 . The process of speciation occasionally results from the isolation of much larger portions of a species. Se ELDREDGE, TIME FRAMES, supra note 19 , at 116.

52. These changes are "rapid" only in ecological or geological terms: an episode of "rapid" speciation may take 5000 to 50,000 years. SeELDREDGE, TIME FRAMES, su pra note 19, at 121.

53. See Eldredge \& Gould, supra note 48, at 203. A central measure of whether two populations of organisms are part of the same species is termed the "reproductive criterion" for delimiting species - whether the two populations interbreed in nature. See ELDREDGE, TIME FRAMES, supra note 19, at 116-17.

54. This description of evolutionary theory is consistent with the fossil ecord, which generally contains abrupt transitions and few intermediate forms (a fact that classical Darwinists, including Darwin himself, explain as merely a reflection of the imperfect fossil record). Se Eldredge, Time Frames, supra note 19, at 21-22; Gould, The Panda's Thumb, supra note 50, at 189; Eldredge \& Gould, supra note 48, at 199; se also STEPHEN JAY GouLD, Wonderful LifE: The Burgess Shale ANd THE NATURE OF History (1989) (describing the Burgess Shale of British Columbia, a major fossil locality, and exploring its implications for evolutionary theory). Darwin devoted two chapters of $\mathrm{O} n$ the Origin of Species by $\mathrm{M}$ eans of $\mathrm{N}$ atural Selection to explaining the discontinuity between his theory of evolution and the fossil record. See ELDREDGE, TIme FRAmes, supra note 19, at 25-26 (discussing Darwin's defense of his evolutionary theory in the face of the fossil record evidence). 
indeterminate because punctuated equilibria are marked by "contingency": "the inability of the theory to predict or explain, either deterministically or probabilistically, the occurrence of a specific outcome." ${ }^{55} \mathrm{~A}$ contingent event is not necessarily random, but it cannot be explained by the variables available to theorists. For example, biologists would treat a cold winter as contingent because it is outside the explanatory framework of biological theories. Because it is marked by contingency, the punctuated equilibria model is unable to predict the arrival of periods of rapid change in advance. Once a period of change has occurred, however, the theory specifies that a new period of stability shaped by the changes that occurred during the most recent punctuation will follow.

Despite their differences, classical evolutionary theory and new evolutionary theory agree that the evolutionary changes of the past directly determine the possibilities for today and tomorrow. As a result, both theories posit, evolutionary processes do not always, or perhaps even often, result in a perfectly optimal outcome. ${ }^{56}$ The creatures that arise out of evolutionary processes may be better adapted to their environment than species that failed to survive, ${ }^{57}$ but they are far from perfect. A famous example of the odd arrangements that arise out of the process of evolution is the so-called panda's thumb: a sixth digit that grew out of the radial sesamoid (normally a small component of the wrist) of the existing anatomy of the panda's forebears. ${ }^{58}$ The "thumb" is awkward and far from perfect, but it allows the panda to strip leaves fairly effectively and efficiently from its main food source, bamboo shoots. ${ }^{59}$ This clumsy but workable solution is strong evidence of the evolutionary path that led to it. ${ }^{60}$

Evolutionary theory thus provides two competing models of the pattern of change in natural systems: one describes a process of slow and steady change and the other a process of long periods of stasis followed by brief periods of rapid change. In both, developments in the past constrain the processes of change in important and predictable ways. These characteristics

55. Mah oney, supra note 12 , at 7.

56. As Stephen Jay Gould notes, "you cannot demonstrate evolution with perfection because perfection need not have a history." GOULD, THE PANDA'S THUMB, supra note 50, at 28.

57. This assumes, of course, that the environment has not changed substantially since the selection process took place. Indeed, it is possible that a species that died out in one environ ment might have flourished in an environment that emerged after its extinction.

58. Se id. at 21-22; see also Stephen J. Gould \& R. Lewontin, The Spandrels of San M arco and the Panglossian Paradigm: A Critique of the Adaptationist Programme, B 205 PROC. ROYAL SOC'Y LONDON 581, 581 (1979) (arguing that the process of evolution is "so constrained by phyletic heritage, pathways of development and general architecture that the constraints themselves become more interesting and more important in delimiting pathways of change than the selective force that may mediate change when it occurs"). But see DENNETT, supra note 47, at 267-82 (critiquing Gould and Lewontin's view of adaptation).

59. See GOULD, THE PANDA'S Thumb, supra note 50, at 21.

60. Seeid. at 29 . 
are not exclusive, however, to biological evolution. As Part II demonstrates, the processes of biological change parallel patterns of change in the law and can help us better understand the process of change in the common law system.

\section{Sequencing Path Dependence}

Social choice theory and game theory offer yet another overlapping but distinct variant of path dependence: sequencing path dependence. This variant of path dependence draws from these literatures the simple but important observation that even when actors are rational and have wellspecified preferences, the order in which alternatives are presented can significantly affect the outcome.

This insight is rooted in one of social choice theory's early and still central observations: Kenneth J. Arrow's "General Impossibility Theorem." ${ }^{11}$ In brief, Arrow's theorem states that when there are three or more choosers and three or more alternative outcomes, "no method of amalgamating individual judgments can simultaneously satisfy some reasonable conditions of fairness on the method and a condition of logicality on the result," ${ }^{62}$ if logicality is defined as a complete and transitive ordering of alternatives. ${ }^{63}$ In other words, it tells us that when there are three or more choosers and three or more alternatives, no selection process can be both fair and logical. This is true of virtually any group selection procedure that one might devise. Indeed, Arrow's theorem implies that "an intransitive social ordering of outcomes can characterize a group that uses nearly any procedure for ordering alternatives (short of dictatorship in which one member's preference is decisive)." ${ }^{\prime 64}$ This prediction holds true even when all individuals are entirely rational, that is, each individual's preferences are

61. Kenneth J. Arrow, Social Choice and Individual Values $46-60$ (2d ed. 1963) [ hereinafter ARROW, SOCIAL CHOICE]. The theorem is also known as the "General Possibility Theorem." WILLIAM H. RIKER, LIBERALISM AGAINST POPULISM 116 (1982).

62. RIKER, supra note 61, at 116.

63. See ARRow, SOCIAL CHOICE, supra note 61, at 22-32, 46-60. Arrow's conditions of fairness, as summarized and restated by Riker are: (1) universal admissibility of individual orderings; (2) monotonicity (the social ordering responds positively to alterations in individual values, or at least not negatively); ( 3 ) citizens' sovereignty or nonimposition of the outcome; (4) unanimity or pareto optimality (if everyone prefers $x$ to $y$, then the social choice function does not choose y) ; (5) independence of irrelevant alternatives-that is, the choice to be made among a set $S$ of alternatives is independent of the preferences of individuals for alternatives not in S; (6) nondictatorship (there is no person who can dictate the outcome). RIKER, supra note 61 , at 116-19. The definition of rationality or logicality as requiring, at a minimum, transitivity, has long been widely accepted by scholars (though not without some dissent). See William H. Riker, The Paradox of Voting and Congressional Rules for Voting on Amendments, 52 AM. POL. SCI. REV. 349, 350-52 (1958). For a formal proof of Arrow's theorem, see DENNIS C. MUELLER, PUBLIC CHOICE 186-88 (1979).

64. Peter C. Ordeshook, A Political Theory Primer 25 (1992). 
complete and transitive..$^{65}$

Where there is intransitivity in social orderings, path dependence necessarily exists, for where there is intransitive social ordering of outcomes, the path by which the alternatives are presented must affect the outcome. ${ }^{66}$ Arrow himself recognized this phenomenon in a passage in the second edition of Social Choice and Individual Values, ${ }^{67}$ which he added in response to charges, made after the publication of the first edition, that he was illegitimately transferring properties of individual choice to social choice. ${ }^{68}$ Arrow wrote, "the importance of the transitivity condition" involves "the independence of the final choice from the path to it." 69 "Transitivity," he explained, "will insure this independence; from any environment, there will be a chosen alternative, and, in the absence of a deadlock, no place for the historically given alternative to be chosen by default." ${ }^{\prime 70}$ Citing the work of Robert Dahl and William Riker, he noted that intransitive social choice mechanisms may produce "decisions that are clearly unsatisfactory." ${ }^{71} \mathrm{He}$ thus concluded that "collective rationality" was not "an illegitimate transfer from the individual to society, but an important attribute of a genuinely democratic system capable of full adaptation to varying environments." 72

As Arrow recognized, if a social choice system is intransitive, outcomes depend on the procedural structure within which they are determined. The power to set the agenda can thus become, in a very real sense, the power to

65. N otably, rational choice theorists bracket the issue of preference formation, generally assuming that actors are rational-that is, that they act to maximize their self-interest. Self interest, in turn, is derived from the structure of the situation.

66. Path independence is defined and justified by one scholar as follows:

$[T]$ he process of choosing, from a dynamic point of view, frequently proceeds in a type of "divide and conquer" manner. The alternatives are "split up" into smaller sets, a choice is made over each of these sets, the chosen elements are collected, and then a choice is made from them. Path independence, in this case, would mean that the final result would be independent of the way the alternatives we re initially divided up for consideration.

Charles R. Plott, Path Independence, Rationality, and Social Choice, 41 EconometricA 1075, 107980 (1973). More precisely, path independence exists when, "for any pair of sets $S$ and T, the choice from the union of the sets is the same as the choice from the union of the separate choices from each set." RIKER, supra note61, at 134.

67. ARRow, SOCIAL CHOICE, supra note 61 .

68. Plott, supra note 66, at 1078. Plott argues that Arrow's defense of the rationality condition is not entirely convincing, as rationality (defined as transitive and complete ordering of preferences) is not necessary for path independence: While all intransitive social ordering will lead to path dependence, not all social ordering mechanisms that are path independent are rational. Id. at 1075, 1090. The accuracy of this argument is not relevant to the inquiry here, as I am concerned with the observation, not contested by Plott, that intransitive (and hence irrational) social ordering mechanisms result in path dependence.

69. ARROW, SOCIAL CHOICE, supra note 61, at 120.

70. Id.

71. Id.

72. Id. 
determine the result. This can be illustrated with a simple example. Assume that a group uses majority rule to rank three alternatives, $A, B$, and $C$. Individual 1 prefers $A$ over $B$ and $B$ over $C$. Individual 2 prefers $C$ over $A$ and A over B. Individual 3 prefers B over C and C over A. Each individual's preferences are entirely complete and transitive. However, the result of these preferences in a majority voting system, assuming voters vote sincerely rather than strategically, is intransitive: A defeats $B, B$ defeats $C$, and $C$ defeats $A$. This result is known as the Condorcet par adox. ${ }^{73}$

Political scientists have explored and expanded this basic insight. For example, a large body of literature has investigated the interplay between agenda structure and voting strategy in legislatures and committees. The foundational work in this area, Robin Farquharson's 1969 Theory of Voting, ${ }^{74}$ demonstrates how the Condorcet paradox arises from the strategic aspects of sequential voting. The literature has arrived at a startling result: If voters vote sincerely rather than strategically, that is, they express their true preferences between alternatives rather than look ahead to final consequences, ${ }^{75}$ then the agendasetter (who determines the procedure by which the outcome is chosen) can nearly dictate the outcome. ${ }^{76}$ This, too, can be demonstrated with a simple example. ${ }^{77}$ Consider three actors who have the preferences listed below, ordered from most preferred to least.

\begin{tabular}{|l|l|l|l|}
\hline $\begin{array}{l}\text { Person 1's } \\
\text { preferences }\end{array}$ & $\begin{array}{l}\text { Person 2's } \\
\text { preferences }\end{array}$ & $\begin{array}{l}\text { Person 3's } \\
\text { preferences }\end{array}$ & $\begin{array}{l}\text { Majority's } \\
\text { preferences }\end{array}$ \\
\hline $\mathrm{x}$ & $\mathrm{y}$ & $\mathrm{z}$ & $\mathrm{x}$ \\
\hline $\mathrm{y}$ & $\mathrm{z}$ & $\mathrm{x}$ & $\mathrm{y}$ \\
\hline $\mathrm{z}$ & $\mathrm{x}$ & $\mathrm{y}$ & $\mathrm{z}$ \\
\hline & & & $\mathrm{x}$ \\
\hline
\end{tabular}

73. The Condorcet paradox gets its name from the Marquis de Condorcet, who is widely regarded as the first to recognize it. See AVINASH K. DIXIT \& BARRY J. NALEBUfF, THINKING STRATEGICALLY 267-70 (1991) (discussing the paradox); ORDESHOOK, supra note 64, at 24-25 (same).

74. ROBIN FARQUHARSON, THEORY OF VOTING ( 1969).

75. Farquharson explained that when voters act sincerely, "their votes are directly in accordance with their preference scales." Id. at 17.

76. See, e.g., Thomas H. Hammond, Agenda Control, Organizational Structure, and Burea ucratic Politics, 30 AM. J. POL. SCI. 379, 381-82 (1986) (demonstrating that for sincere voting under either successive or amendment procedure, any proposal could be made the voting decision, given an appropriate order of voting); Nicholas R. Miller, Graph-Theoretical Approaches to the Theory of Voting, 21 AM. J. POL. SCI. 769, 780-83 (1977) [hereinafter Miller, Graph-T heortical A pproaches] (same); Riker, supra note 63, at 362-63 (same).

77. This example is drawn directly from $\mathrm{H}$ ammond, supra note 76 , at 381-82. 
These preferences produce the following outcome in a system of successive pairwise majority votes: In a majority vote, $x$ would beat $y, y$ would beat $z$, and $z$ would beat $x$. If the agenda is unconstrained, chaos results. Notice, however, that there are three possible binary agendas that could be used to choose among these alternati ves:

(1) Compare $x$ and $y$, and then pit the winner against $z$.

(2) Compare $x$ and $z$, and then pit the winner against $y$.

(3) Compare $y$ and $z$, and then pit the winner against $x$.

Each agenda yields a different final winner. Thus, whoever determines the agenda al so determines the outcome. ${ }^{78}$

The effect of the agenda on the outcome is significantly reduced, however, when voters are strategic or sophisticated. A sophisticated voter "reaches conclusions about what will happen by successively eliminating categories of events that certainly will not happen." ${ }^{79}$ In effect, the sophisticated voter works backward from the result to determine the best course of action at each juncture. ${ }^{80}$ Thus, "sophisticated voting under successive procedure works as if the last two proposals in the voting order were paired for a sincere majority vote." 81 Because of the forward-looking nature of sophisticated voters, the sophisticated voting decision under successive procedure always results in a decision within the "Condorcet set"-the set of outcomes of a social choice function such that no point outside the set beats or ties any point in the set in a paired comparison. ${ }^{82}$

78. This conclusion appears to survive experimental testing. In an early test of an agendasetter's power to determine outcome, Charles Plott and Michael Levine performed experiments in which a random group of individuals chose among sets of limited alternatives to test the influence of agendas on outcomes. The experiments supported the scholars' claim that where an agenda is fixed, it influences outcomes by limiting the information available to decision makers about the patterns of preference in the group and by determining the set of strategies available to the individual. See Charles R. Plott \& Michael E. Levine, A M odel of Agenda Influence on Committe Decisions, 68 AM. ECON. REV. 146, 147 (1978) (discussing the strategies available). For more on the power of the agenda-setter to determine outcome, see generally Richard $D$. McKelvey, General Conditions for Global Intransitivities in Formal Voting M odels, 47 ECONOMETRICA 1085 (1979); Kenneth A. Shepsle \& Barry R. Weingast, Uncovered Sets and Sophisticated Voting Outcomes with Implications for Agen da Institutions, 28 AM. J. PO LI. SCI. 49, 60 (1984).

79. FARQUHARSON, supra note 74, at 39-40.

80. See, e.g., James M. Enelow \& David H. Koehler, The Amendment in Legislative Strategy: Sophisticated Voting in the U.S. Congress, 42 J. POL. 396, 399 (1980) (noting that scholars have shown, in variety of contexts, that the agenda has less influence on outcome when voters are sophisticated); Miller, supra note 76, at 799 (demonstrating that where there is sophisticated voting under an amendment procedure, there might be proposals that could not be made the outcome under any order of voting); Nicholas Miller, A N ew Solution Set for Tournaments and M a jority Voting: Further Graph-Theoreical A pproaches to the Theory of Voting, 24 AM. J. POL. SCI. 68 passim (1980) (demonstrating that sophisticated voting under amendment procedure resultsin Pareto-optimal decisions) ; Shepsle $\&$ Weingast, supra note 78, at 69 (demonstrating that open agenda processes with sophisticated voters will result in Pareto-optimal outcomes).

81. Miller, Graph -T heoretical A pproaches, supra note 76, at 785.

82. See id. at 786 (describing the Condorcet set). 
Thus, it is not possible for the agendasetter to manipulate the agenda so that an outcome outside the Condorcet set results. ${ }^{83}$ Nevertheless, the influence of the agenda is not erased: The agenda may still determine which point within the Condorcet set is ultimately selected by the social choice process. Indeed, sophisticated voting under successive procedure may result in a proposal being adopted, even when every voter prefers some other proposal. $^{84}$

A similar phenomenon can occur in strategic games among rational players. Where there are multiple possible equilibria, the order in which players in the game "move" influences which of the possible equilibria will be the game's endpoint. A simple illustration of this is the classic coordination game. ${ }^{85}$ In the most basic coordination game, there are two players and two possible meeting locations. Each player receives a positive payoff if both players go to the same location, a higher payoff if they meet in the player's preferred location, and no payoff if they fail to meet. There are four possible outcomes or equilibria. ${ }^{86}$ If player $A$ is able to make the first move, and player B knows that move (or player A's preferred location), then player $A$ can determine which of the possible equilibria will result. Player $B$ will go to player A's preferred location, even if player B's payoff would be greater if the two players met at a location different from that chosen by player $A$, because this is the only way in which player $B$ can be assured of a positive payoff. The "first mover" in this example can thus use her agendasetting power to obtain the outcome most favorable to her. Once again the sequence of choices or moves determines the outcome. ${ }^{87}$

83. See, e.g., id. at 789 ( " $[\mathrm{S}]$ ophisticated voting under any binary procedure complies with the Condorcet criterion.").

84. Miller explainsthisfinding well:

At first glance, it may appear that the Pareto criterion is redundant in conjunction with the Condorcet criterion - that is, it might seem that any proposal meeting the latter condition meets the former as well. But in fact the two criteria are independent, and the Condorcet set may include proposals that fail to be Paretooptimal. Suppose there are four proposals, $x, y, z$, and v, and three voters: voter 1 prefers $v$ to $x, y$ to $z$, voter 2 prefers $z$ to $v$ to $x$ to $y$, and voter 3 prefers $x$ to $y$ to $z$ to $v$.... Proposal $x$ is unanimously preferred to $y$ and so, while all four proposals belong to the Condorcet set, only $x, z$, and $v$ are Pareto-optimal.... [ [ ] t follows that ... both sincere and sophisticated voting under successive procedure may fail to comply with the Pareto criterion - that is, in these cases a voting body may adopt a proposal $y$ even when every voter prefers some other proposal $x$ to $y$.

Id. at 792-93.

85. For a more in-depth explanation of cooperative game theory and several simple coordination game models, see Jon ELSTER, EXPLAINING TECH NICAL CHANGE: A CASE STUdY IN THE PHILOSOPHY OF SCIENCE 77-83 (1983).

86. Where the parties have incomplete information, the game is "both logically consistent and indeterminate" with respect to outcomes. Stephen M. Walt, Rigor or Rigor M ortis?: Rational Choice and Security Studies, 23:4 INT'L SECURITY, Spring 1999, at 5, 20.

87. A similar result can be derived from a variety of game theoretic models. For example, 
Game theory and rational choice theory thus describe a third form of path dependence that provides yet another view of how the path of history can shape processes of change. In systems that demonstrate this form of path dependence, the sequence in which the alternatives are consideredor the path by which they are selected-can influence the outcome. This prediction applies to a variety of contexts, including, as Part II demonstrates, the common law system.

With the essential attributes of the three forms of path dependence established, Part II of this Article turns to an examination of path dependence theory's relevance to the common law legal system. I seek to demonstrate that each variant of path dependence describes important aspects of the common law system and thus can be used to better understand the development of legal rules in common law legal systems.

\section{The Path Dependence Of The Common LAW System}

Path dependence theory is relevant to the common law system for a simple reason: the doctrine of stare decisis. Under the doctrine of stare decisis et non quieta movere- "let the decision stand and do not disturb things which have been settled"88-decisions of higher courts are controlling in subsequent cases involving similar circumstances. ${ }^{89}$ Courts also give their own prior decisions great weight, though they are not strictly bound to follow their own precedents. ${ }^{90}$ Furthermore, even when decisions of other

game theory also predicts "herd behavior" where there are problems of information aggregation. Under this theory, the first player to make a choice bases his decision on the information that he possesses about the available alternatives. Subsequent players, however, consider not only the information that they possess but also the decisions of those who chose before them. Under these circumstances, game theory predicts that where the players make their decisions sequentially and are informed of the decisions of those who precede them, all the players will follow the lead of the first. That is true even if the information possessed by the group as a whole overwhelmingly suggests that the other alternative is better. Se DoUGLAS G. BAIRD ET AL., GAME THEORY AND THE LAW 213-17 (1994) (illustrating this theory with hypothetical examples).

88. Stevens, supra note 2, at 1 n.2 ( citation omitted).

89. See John C. GRay, The Nature ANd SOURCES Of the LaW 211 (Roland Gray ed., M acmillan 2d ed. 1921) (1972) [ hereinafter GRAY, NATURE AND SOURCES].

90. Indeed, as a general rule, an American court does not consider itself inexorably bound by its own precedents, but, in the interest of uniformity of treatment to litigants, and of stability and certainty in the law ... will follow the rule of law which it has established in earlier cases unless clearly convinced that the rule was originally erroneous or is no longer sound because of changed conditions and that more good than harm would come by departing from precedent.

James W. M oore \& Robert S. O glebay, The Supreme Court, Stare Decisis, and the L aw of the Case, 21 TEX. L. REV. 514, 539-40 (1943). John C. Gray has noted:

We have seen that the $\mathrm{H}$ ouse of Lords will not overrule its own prior decision. ... No such doctrine prevails in America; the highest courts in the respective States and the Supreme Court of the U nited States all consider that they have the power, 
courts are not explicitly binding, they can provide persuasive authority. ${ }^{91}$ Judges who follow the doctrine thus generally apply decision rules that entail explicit reliance on earlier choices and thereby generate path dependence.

This is a broad-brush description of the role of precedent in a common law system. Under closer scrutiny, the picture is more complex. ${ }^{92}$ What

however inexpedient it may be to exercise it, to depart from their former rulings.

Gray, NATURE AND SourCes, supra note 89, at 242; se also Benjamin N. CARdozo, The Nature OF THE JUdiCIAL PROCESS 158 (1921) ("The United States Supreme Court and the highest courts of the several states overrule their own prior decisions when manifestly erroneous."). Some courts require that the court meet en banc in order to overrule a previous decision. The Federal Circuit's Rules, for example, include the following provision:

Although only the court en banc may overrule a binding precedent, a party may argue, in its brief and oral argument, to overrule a binding precedent without petitioning for hearing en banc. The panel will decide whether to ask the regular active judges to consider hearing the case en banc.

FED. CIR. R. 35(a)(2). Other courts establish specific procedures that a panel must follow in order to overrule a previous decision. For example, in the Seventh Circuit, a panel must circulate an opinion to the full court before overruling a previous Seventh Circuit opinion. Rule 40(e) states:

A proposed opinion approved by a panel of this court adopting a position which would overrule a prior decision of this court or create a conflict between or among circuits shall not be published unless it is first circulated among the active members of this court and a majority of them do not vote to rehear en banc the issue of whether the position should be adopted.

See 7TH CIR. R. 40(e). And several federal circuit courts have adopted rules that establish disagreement with a previous decision in the same court as one of two or three bases for en banc review. See, e.g., FED. R. APP. P. 35(b) (1) (B) (stating that a petition for rehearing en banc may be granted if the petition alleges that "the panel decision conflicts with a decision of the U nited States Supreme Court or of the court to which the petition is addressed ( with citation to the conflicting case or cases) and consideration by the full court is therefore necessary to secure and maintain uniformity of the court's decisions"); B CIR. R. 35.1 (requiring en banc petitioner to state that: "I express a belief, based on a reasoned and studied professional judgment, that the panel decision is contrary to decisions of the United States Court of Appeals for the Third Circuit or the Supreme Court of the United States...."); 6TH CIR. R. 35(c) ("A suggestion for rehearing en banc is an extraordinary procedure which is intended to bring to the attention of the entire Court a precedent-setting error of exceptional public importance or an opinion which directly conflicts with prior Supreme Court or Sixth Circuit precedent."); 11TH CIR. R. 35-6(c) (requiring a similar statement); FED. CIR. R. 35(b) (2) (same).

91. Occasionally, courts have even adopted rules that encourage consistency among courts in different jurisdictions. For example, in the Seventh Circuit, before issuing an opinion that will create a split in the circuits on a substantive legal issue, a panel must circulate an opinion to the full court. 7TH CIR. R. 40(e) (requiring that any proposed panel opinion that would createa circuit split be circulated to the full court before publication). Similarly, several federal circuit courts have established rules that make a split in authority with a sister jurisdiction a basis for en banc review. Se, eg., FED. R. APP. P. 35(b) (1) (B) ("[A] petition [for rehearing en banc] may assert that a proceeding presents a question of exceptional importance if it involves an issue on which the panel decision conflicts with the authoritative decisions of other U nited States Courts of Appeals that have addressed the issue."); FED. CIR. R. 35 (b) (1) (B) (same).

92. Some scholars claim that stare decisis strikes "with all the predictability of a lightning bolt," Henry P. Monaghan, Our Perfect Constitution, 56 N.Y.U. L. REV. 353, 390 (1981), and that it 
constitutes precedent in a particular case is a flexible concept that is subject to interpretation, especially when considering cases that are not directly on point. ${ }^{93}$ In practice, courts may interpret a prior decision in such a way that it does not appear to be controlling, even though a strong argument might be made that it is relevant and controlling precedent. Courts may also do the opposite, citing a preceding case as controlling or persuasive precedent when that case is arguably not relevant to the issue at hand ${ }^{94}$ Furthermore, courts may intentionally emphasize some facts and deemphasize others to make a case appear controlling or not, depending on the desired result. As Dean Edward Levi observed, "the scope of a rule of law, and therefore its meaning, depends upon a determination of what facts will be considered similar to those present when the rule was first announced." 95 Determining similarity or difference is essential to the application of precedent and is solely the function of the court in the present case. Indeed, "the judge in the present case may find irrelevant the existence or absence of facts which prior judges thought important." 96

Although the concept of precedent is flexible, it does have meaning and effect. As Justice Benjamin Cardozo observed, precedents "fix the point of departure from which the labor of the judge begins." ${ }^{97}$ Courts remain, at least to some extent, constrained by previous decisions. ${ }^{98}$ The reasons for this are several-fold. First and most obviously, judges recognize that their

is a "doctrine of convenience to both conservatives and liberals... [whose] friends... are determined by the needs of the moment." Charles J. Cooper, Stare Decisis: Precedent and Principle in Constitutional Adjudication, 73 CORNELL L. REV. 401, 402 (1988); see also Max Radin, The M thod of Law, 1950 WASH U. L.Q. 471, 484 (arguing that a major function of legal education is to teach law students to manipulate precedent).

93. The flexibility of precedent is often seen in cases where opposing parties each provide lines of precedent that they claim to be controlling, but which lead to opposite results. In such circumstances, the court may choose either line based solely on the desired result and, assuming the arguments made for each are at least plausible, remain entirely faithful to the principle of precedent.

94. Indeed, some legal realists have questioned whether precedents are simply smoke screens for judges' political and personal preferences. Se, eg., JEROME FRANK, LAW AND THE M ODERN M IND 148-59 (1930). An empirical test of the influence of precedent on decisions of Supreme Court Justices - who are the least controlled by precedent due to their position at the pinnacle of the American legal system and the Supreme Court's tendency to only acceptcases for review that are not clearly controlled by its earlier decisions-indicates that they cited it at conference as an important element in their decision making process in a little over one quarter of cases. See LEE EPSTEIN \& JACK KNIGHT, THE CHOICES JUSTICES M AKE 30 (1998). This suggests that precedent is, at least rhetorically, an important element in judicial decision making.

95. Edward H. Levi, An Introduction to L egal Reasoning, 15 U. CHI. L. REV. 501, 502 (1948) [ hereinafter E. Levi, Introduction].

96. Id.

97. CARDOZO, supra note 90 , at 20.

98. See id. at 19-20. The exception to this general principle is, of course, the Supreme Court, which is constrained only inasmuch as it desires to be. 
decisions may be overruled if they are too dismissive of prior precedent, thus depriving their decision of any legal effect. ${ }^{99}$ Judges also follow precedent to preserve their reputations and prestige. ${ }^{100}$ This may be a particularly strong incentive for a judge who wishes to be appointed to a higher court. Moreover, judges follow precedent because they know that if they regularly fail to do so, they risk treatment in kind by their fellow judges. ${ }^{101}$

Yet judges are not simply constrained by precedent. They also benefit greatly from it and thus have reason to support its continued vitality. ${ }^{102}$ Precedent binds future judges to respect the decisions of current judges, expanding the influence of current judges beyond cases in which they participate to cases that may arise long after they have left the bench. To be sure, there may be something of a collective action problem inherent in maintaining the principle of precedent. ${ }^{103}$ In any individual case, a judge

99. See Richard A. Posner, Economic AnAlysis of LAW 542 (4th ed. 1992) ("The judge who disregards precedent will be reversed by a higher court that has no interest in letting him impair the practice of decision according to precedent in order to magnify his own influence."); Richard A. Posner, What do Judges M aximize? (The Same Thing Everybody Else Does), 3 Sup. CT. ECON. ReV. 1, 13 (1993) [hereinafter Posner, What do Judges Maximize?] (including "popularity, prestige, and avoiding reversal" in a "judicial utility function").

100. See Posner, What do Judges M aximize?, supra note 99, at 6 (1993) (finding that "a potentially significant element in the judicial utility function is reputation") (emphasis omitted).

101. For example, a lower court judge who regularly ignores the precedent set by a particular higher court might find her future decisions viewed more skeptically by that court. Similarly, a judge who is quick to dismiss the precedent set by a judge or panel on the same court may find other judges on that court treating her decisions with similar disrespect.

102. See, e.g., POSNER, supra note 99, at 541 ("A precedent projects a judge's influence more effectively than a decision that will have no effect in guiding future beh avior. This. . . suggests why judges follow as well as make precedent. ..."); Frank H. Easterbrook, Ways of Criticizing the Court, 95 HARV. L. REV. 802, 817 (1982) ("[E] ach Justice may find it advantageous to follow rules announced by his predecessors, so that successors will follow his rules in turn. Stare decisis thus enhances the power of the Justices."); William M. Landes \& Richard A. Posner, Legal Precedent: A Theoretical and Empirical Analysis, 19 J.L. \& ECON . 249, 273 (1976) (suggesting that it is to judges' advantage to follow precedent so that their successors do the same); Eric Rasmusen, Judicial Legitimacy as a Repeated Game, 10 J.L. ECON \& O RG. 63 (1994) (using a game theoretic model to demonstrate that given the proper climate of expectations and norms of judicial behavior, even purely self-interested judges will follow precedent to maximize their own influence in the future).

103. The term "collective action problem" refers to the predicted underproduction of collective or public goods-goods that exhibit nonrivalry in consumption (i.e., when one individual's consumption does not interfere with another's) and nonexcludability (i.e., when it is either impossible or at least difficult to prevent any individual from enjoying the good once it is supplied). Collective action theory predicts that large groups will underprovide collective goods because each member of the group will refuse to pay his share of the costs of producing or providing the good (e.g., members will "defect" or "free ride"). Se Joanne Gowa, Public Goods and Political Institutions: Trade and M onetary Policy Processes in the United States, in THE STATE AND AMERICAN Foreign ECONOMIC POLICY 20-21 (G. John Ikenberry et al. eds., 1988) (explaining collective action problem). Se generally MANCUR OLSON, THE LOGIC OF COLLECTIVE ACTION: PUBLIC GOOdS AND THE THEORY OF GROUPS (1965) (discussing, in detail, the economic and "group theory" basis for the collective action problem). 
receives the full benefits from defection but shares the costs of the harm to the principle of precedent with all other judges. But judges are arguably sufficiently "privileged actors"-their numbers are relatively small, particularly within each line of authority-that the collective action problem can be overcome. ${ }^{104}$ And, of course, there are individual costs of defection that make defection less attractive. ${ }^{105}$

The rule of precedent also benefits judges by reducing their workload. Reliance upon precedent makes it possible for judges to put less labor into each individual case. As Justice Cardozo once remarked, "the labor of judges would be increased almost to the breaking point if every past decision could be reopened in every case, and one could not lay one's own course of brick on the secure foundation of the courses laid by others who had gone before him." ${ }^{106}$ By relying on past decisions, judges can save significant time and effort and thereby consider far more cases than would otherwise be possible. Judges can turn to past malyses and avoid rethinking every aspect of a decision. ${ }^{107}$ Indeed, this may help explain why the Supreme Court, which generally considers cases that involve unsettled principles of law, resolves far fewer cases than lower courts that can often rely more heavily on precedent. ${ }^{108}$ Even at the Supreme Court level, however, not every issue raised by a case is considered anew. As Justice Powell once noted, "[f]ew cases that reach the Supreme Court are easy. Most involve hours of study and reflection; the conscientious judge must make many close calls. It

104. A "privileged" group or actor is a group "such that each of its members, or at least some of them, has an incentive to see that the collective good is provided, even if he has to bear the full burden of providing it himself." O LSON, supra note 103, at 49-50.

105. Sesupra text accompanying notes 98-101.

106. CARDOZO, supra note 90, at 149; see also RICHARD A. WASSERSTROM, THE JUdICIAL DECISION: TOWARD A THEORY OF LEGAL JUSTIFICATION 72-74 (1961) (detailing the efficiency justification for precedent); Earl Maltz, The Nature of Precedent, 66 N.C. L. REV. 367, 370 (1988) ( "[T] he ability to rely on precedent no doubt simplifies the task of judging.").

107. The use of precedent not only makes it possible for judges to complete what might otherwise be an insurmountable amount of work, but it also allows them to do so relatively quickly, leaving time for leisure or other preferred pursuits. See Posner, What do Judges M aximize?, su pra note 99 , at 13 (observing that judges value leisure).

108. See H.W. PeRrY, JR., DeCIDING TO DECIDE 22 (1991) (noting that the Supreme Court takes a small proportion of the cases appealed to it); William T. Coleman, Jr., T heSu premeCourt of the U nited States: M anaging Its Caseload to Achievel ts Constitutional Purposes, 52 FORDHAM L. REV. 1, 2-5 (1983) (suggesting that the Court's caseload must be limited to allow the Court to fulfill its constitutional purposes and providing data on the number of opinions written by the United States Supreme Court); Leonidas Ralph Mecham, Ju dicial Business of the United States Courts, 1999 Annual Report of the Director, tbl.A-1, at http:/ / www.uscourts.gov/ judbus1999.index.html (visited O ct. 16, 2000) (providing data on the judicial caseload of the U nited States Supreme Court and indicating that 90 cases were argued during the October 1998 term); id. at 16, at http:/ / www.uscourts.gove/ judbus1999.index.html (visited Oct. 16, 2000) (providing data on the judicial caseload for the U nited States Courts of Appeals and United States District Courts and indicating that 54,000 cases were filed in the United States Courts of Appeals in 1998, roughly 4,154 per court). 
cannot be suggested seriously that every case brought to the Court should require reexamination on the merits of every relevant precedent." ${ }^{109}$ The doctrine of stare decisis may also contribute to a lower volume of liti gation, and thus a smaller workload for judges, as the legal certainty that it fosters leads more individuals to choose settl ement over litigation. ${ }^{110}$

Perhaps most important, judges conform to the doctrine of stare decisis because the principle of precedent is deeply ingrained in our AngloAmerican legal culture. Most lawyers in the United States have internalized the doctrine of stare decisis and obey it reflexively. ${ }^{111}$ They accept the principle that treating like cases alike is an important element of legal justice and necessary to the functioning of the legal system. Moreover, judges often follow a precedent for the simple but obvious reason that they find its reasoning compelling. Therefore although lawyers and judges are often eager to bend precedent to serve their ends, they generally do not wish to abandon it.

Thus, although the doctrine of stare decisis is flexible, it does lead judges to look to previous decisions. The system of stare decisis thereby creates an explicitly path-dependent process in which later decisions rely on, and are constrained by, earlier decisions. More specifically, as I argue below, the legal structure of the common law system generates increasing returns, evolutionary, and sequencing path dependence. These three types of path dependence operate concurrently, with varying degrees of prominence, depending on the area of law and specific legal issue. By examining these specific path-dependent features and their consequences, we can gain greater insight into how our legal process works and how our legal structure has shaped, and continues to shape, legal outcomes.

\section{A. INCREASING RETURNS PATH DEPENDENCE}

Perhaps the most obvious and striking path-dependent features of the common law system are those that fall under the rubric of increasing returns path dependence. Increasing returns in a common law system derive directly from reliance upon precedent. The common law system operates through the gradual building of legal rules upon one another over time. Not only does an earlier decision influence the later decisions of courts, but it also influences them in a particular way: It makes it more likely that courts will choose to resolve similar legal dilemmas in a similar manner. In the process

109. Lewis F. Powell, Jr., Stare Decisis and Ju dicial Restraint, 62 N.Y. ST. B.J. 15, 18 (July 1990).

110. POSNER, supra note 99 , at 542 . Once an issue is settled by a court, parties with similar legal disputes have a preview of the likely result of their own case and a consequent incentive to settle the issue without incurring the costs of litigation.

111. Indeed, much of legal education is based on the notion of stare decisis, therefore lawyersin-training are necessarily exposed to the arguments in favor of stare decisis implicitly, if not explicitly. Se supra note 5 and accompanying text ( discussing the arguments made in favor of stare decisis); infra notes 193-202 and accompanying text ( same). 
of accretion, "there is a tendency toward the reproduction of kind. Every judgment has a generative power. It begets in its own image."112 Every precedent "has 'a directive force for future cases of the same or similar nature.'"113 Thus, each step taken in one direction increases the likelihood of additional steps in that same direction.

Other factors reinforce the increasing returns nature of the common law system in addition to the formal doctrine of stare decisis. For instance, the process of judging generates significant learning effects. ${ }^{114}$ Judges accumulate experience and knowledge over time. Inevitably, they see similar issues raised repeatedly. A judge may draw on earlier analogous cases in deciding later cases even if they do not strictly constitute a binding or persuasive precedent. For example, a judge may rely on a case that decides an issue in dicta or in a dissimilar factual situation and thus does not constitute formally binding precedent. While not bound to follow the case by any rule of precedent, the judge may nonetheless draw on the insights and knowledge gained from such cases.

The common law system also generates significant self-reinforcing or adaptive expectations. Litigants are unlikely to make arguments that stray from existing law (as created, shaped, and revealed by prior precedent), because they know that doing so would significantly decrease their likelihood of success and perhaps even risk sanctions for putting forward an argument with an insufficient legal basis. ${ }^{115}$ Thus litigants bring suits that are factually consistent with previous cases and make arguments within the bounds of existing precedent and law. Consequently, when a new precedent emerges, litigants will react to the precedent in ways that further reinforce and contribute to the path indicated by that new precedent: Parties whose favored outcomes become more likely in the wake of the new precedent may be more likely to bring suit and thereby push the law further in that same direction, whereas parties whose desired outcomes become less likely may be discouraged from engaging in litigation, allowing the new path to continue unchecked. Dean Levi observes this dynamic arising out of statutory decisions. He argues that private conduct, future interpretations, and legislative activity all rely and build upon statutory decisions by the courts. ${ }^{116}$ Consequently, courts try cases and hear arguments that are directly shaped

112. Powell, supra note 109 , at 21.

113. CARDOZO, supra note 90, at 22 (quoting Redlich, The Case M ethod in American Law Schools, CARnegie Foundation, Bulletin No. 8, at 37).

114. Se id. at 19 ( "The first thing [a judge does when presented with a case] is to compare the case before him with the precedents, whether stored in his mind or hidden in the books.").

115. FED. R. CIV. P. 11(b), for instance, permits sanctions to be levied against a person if that person violates its provision requiring that "the claims, defenses, and other legal contentions" in any pleading, written motion, or other paper presented to the court "are warranted by existing law or by a nonfrivolous argument for the extension, modification, or reversal of existing law or the establishment of new law."

116. See E. Levi, Introduction, supra note 95, at 523-40. 
by the courts' prior decisions.

The increasing returns path-dependent nature of the common law system is further reinforced by the difficulties of foresight or the "bounded rationality" of the courts. ${ }^{117}$ The principles of justice require judges to consider each case independently. ${ }^{118}$ But even when judges consider future cases, they cannot possibly predict all possible future cases and construct decisions that would have the optimal effect on them. This is not to say that judges do not (or perhaps even should not) bear in mind the possible ramifications of their current decisions on future cases or that judges are not "rational" in the ordinary sense of that word. ${ }^{119}$ Rather, it simply means that judges possess less than complete information regarding the set of future cases and the impact of a particular decision on those future cases.120 Consequently, even when judges seek to create legal rules to advance their positions in the future, they are unable to predict or control whether their decisions will create precedents that will necessarily lead to particular results in future cases.

The conclusion that the common law system exhibits increasing returns path dependence helps to explain and predict the way the system will operate. Indeed, the increasing returns nature of the common law system has three predictable consequences. The first is nonergodicity-small early events have a large impact on the eventual outcome. Because judges cannot fully anticipate the ways in which public and private actors will react to their decisions, they have difficulty determining the likely effect of their decisions over time. For this reason, decisions may have large, unanticipated, and unintended effects. For example, a single sentence in an early case may take on increasing significance over time. When a higher court makes a statement, even in dicta, on a previously undecided or unclear issue, litigants and lower courts often rely upon that statement for guidance. The statement may become the decisive factor in future lower court decisions and even in

117. The term "bounded rationality," as used in political economy literature, refers to the fact that actors often must act upon imperfect or incomplete information. For more on bounded rationality, see HERBERT A. SIMON, MOdELS Of BOUNDED RATIONALITY: BeHAVIORAL ECONOMICS AND BUSINESS ORGANIZATION (1982).

118. But se Fredrerick Schauer, Precedent, 39 StAN. L. ReV. 571, 588-91 (1987) (discussing how judges take into account the expected effect of a case on future cases when making a decision under a legal system where precedent is binding).

119. It also does not suggest that judges do not engage in forward thinking in other contexts. For example, Lee Epstein and Jack Knight argue quite persuasively that members of the Supreme Court take into account the likely preferences of their colleagues and the actions they expect them to take at the merits stage, as well as the likely reactions of other political actors, when deciding how to vote on certiorari petitions. Sœ EPSTEIN \& KNIGHT, supra note 94, at 79-88; see also PERRY, supra note 108, at 198-212 (describing Supreme Court Justices' use of "defen sive denials" and "aggressive grants" in the certiorari process).

120. Even the Supreme Court, which has more control over its docket than any other court in the United States, cannot determine when petitions for certiorari will be filed and, therefore, cannot control or predict what cases will be in the pool of cases with which it will be presented. 
future cases in the same court. Indeed, some judges, understanding this, might even engage in strategic opinion writing-placing unnecessary statements in opinions (which are likely to go unnoticed and therefore unchallenged by fellow judges) to be used by litigants, lower courts, and the judges themselves in subsequent cases. Indeed, one of Justice Stone's law clerks reported that Justice Stone would consciously "plant[] seeds of new concepts in the dicta of his writing... 'like a squirrel storing nuts to be pulled out at some later time.'"121

The nonergodicity of the common law system makes early cases on a legal issue dramatically important. Because the path of the common law is locked in at an early stage, early decisions are crucial to the direction of the law. The first few cases that address a new legal issue frame the law for all future cases raising the same or a similar issue. Path dependence theory thus lends a theoretical grounding to the efforts by legal advocacy groups to control and choose cases that raise novel issues.

An example will help clarify this insight. A single (now very famous) footnote in United States v. Carolene Products, ${ }^{122}$ an opinion issued by the Supreme Court during the New Deal period, is widely regarded as having set the stage for the Warren Court's assumption of an active role in monitoring the political institutions of the country. ${ }^{123}$ The footnote suggested that the Court would apply different degrees of judicial scrutiny to different types of legislation: The Court might lessen the presumption of constitutionality "where legislation appears on its face to be within a specific prohibition of the Constitution, such as those of the first ten amendments"; apply greater scrutiny in reviewing "legislation which restricts those political processes which can ordinarily be expected to bring about repeal of undesirable legislation"; and discount the presumption of constitutionality for "statutes directed at particular religious... or ... national ... or racial minorities."124 Much of the following six decades of Supreme Court case law has been devoted to expanding and specifying the extent to which this suggestion would be implemented. This case thus demonstrates well that small causes can have large effects. ${ }^{125}$

121. WALTER F. MuRPhy, ELEMENTS Of Judicial StRATEgy 203 (1964).

122. 304 U.S. 144 ( 1938).

123. See id. at 152 n.4; 1 ACKERMAN, supra note 3, at 128-29 (stating that the footnote was an effort to reorient the meaning of the reconstruction amendments in the post-NewDeal world); ELY, supra note 3, at 75-77 (explaining that the footnote foreshadowed the Warren Court's assumption of a more "activist" or interventionist role).

124. Carolene Products, 304 U.S. at 152 n.4.

125. A much less prominent example of this phenomenon, but one that indicates its frequency, can be found in Farrar v. H obby, 506 U.S. 103 ( 1992), and S-1 \& S-2 v. StateBoard of Education, 21 F.3d 49 (4th Cir. 1994). In Farrar, the Supreme Court held that the court below had erred in holding that petitioners' nominal damages award had failed to render them prevailing parties. In the course of its opinion, it explained that, "No material alteration of the legal relationship between parties occurs until the plaintiff becomes entitled to enforce a 
The second predictable consequence of increasing returns path dependence in the common law is lock-in or inflexibility. Once a court has resolved a legal issue in a particular way, the doctrine of stare decisis and more informal characteristics of the common law system lock in the legal rule. The principle of stare decisis locks courts into conforming their future decisions to the bounds set by binding precedent. Moreover, while a court may not be strictly bound by its own decision, it is unlikely to diverge from it. And courts in concurrent jurisdictions, though not bound by the decision, may look to it as persuasive precedent-as not strictly binding but lending credence and weight to a party's arguments on a similar legal issue. These characteristics of the common law process lead a particular resolution of a legal issue to become locked in; courts find it increasingly difficult to depart from the path once the first few steps are taken.

Lock-in or inflexibility can, in turn, lead to inefficiency. Early decisions may lead to formation of a legal rule that becomes increasingly inefficient over time. This is true regardless of whether the early decisions are themselves efficient. External circumstances may change, causing what was once an efficient rule to become inefficient in light of the changed context. Or what is an efficient rule in one case may be much less efficient in a somewhat different context. Or new information may become available that changes the perception of the legal issue and its correct resolution. Or, finally, courts may take what was an efficient rule in a narrow set of circumstances and broaden it to encompass a set of circumstances in which it is less efficient.

This implication of path dependence runs directly counter to a significant body of legal scholarship on the efficiency of the common law. Since the 1970s, many scholars subscribing to the law and economics school of thought have glorified the common law on efficiency grounds. As I show in greater detail below, these scholars argue that the common law evolves toward efficient rules for a variety of reasons, including judges' propensity to favor efficient rules, the greater likelihood that inefficient rules will be litigated, and the greater frequency of court settlement in cases in which the legal rules relevant to the dispute are inefficient. ${ }^{126}$ The law and economics

judgment, consent decree, or settlement against the defendant." Farrar, 506 U.S. at 113. Based on this brief statement, arguably made in dicta, the Fourth Circuit later concluded in an unrelated case that a party could not be considered a prevailing party, and thus eligible for attorney's fees, unless it had obtained an enforceable judgment, consent decree, or settlement giving some legal relief. S-1 \& S-2, 21 F.3d at 51. In the course of so concluding, the Fourth Circuit overruled a line of cases in that circuit that had held that where a lawsuit operates as a "catalyst" for post-litigation changes in a defendant's conduct, that was sufficient to establish plaintiff as a prevailing party. Id. Thus, one sentence in a Supreme Court decision was transformed by a lower court into not only a basis for deciding a case but also a ground for overruling a longstanding line of precedent.

126. See infra text accompanying notes 144-51 (summarizing the argument that the most efficient legal rules tend to evolve in a common law legal system). 
account of the common law fails to consider, however, the path-dependent nature of case law development. ${ }^{127}$

The anticipatory reactions of potential litigants may amplify these inefficiencies. Rather than litigate a case that would lead to the most efficient rule, a party may be discouraged by what it perceives to be a clear trend in the case law against its position and thus decide to settle. At the same time, parties that favor an inefficient rule may seek to push the courts to extend its logic further, leading to even more inefficient legal outcomes. Consequently, the courts have fewer opportunities to consider returning to a more efficient rule and may even be pushed by litigants to extend an inefficient legal rule. This process may lead to the legal equivalent of the Q werty keyboard: a legal rule that has become locked in early and that persists despite its inefficiency. An example of this phenomenon can be found in the courts' recent struggles to apply patent rules first developed two centuries ago to newly emerging computer technology. ${ }^{128}$

127. The efficiency argument has been critiqued on other grounds. See generally Robert Cooter \& Lewis Kornhauser, Can Litigation Improve the L aw Without the H elp of Judges?, 9 J. LEGAL STUD. 139 (1980) (putting forward an "impossibility theorem," which states that blind evolution will not cause the legal system to reach the best state or continually to improve itself); Robert Cooter et al., Liability Rules, Limited Information and the Role of Precedent, 10 BELL J. ECON. 366 (1979) (showing that judges have enough information to revise the legal standard for distributing accident costs via the mechanism of precedent so that the standard adopted tends toward efficiency); William M. Landes \& Richard A. Posner, Adjudication as a Private Good, 8J. LEGAL STUD. 351 (1978) (examining the operation of private judicial systems); Sinclair, supra note 6 (providing a critical review of the use of evolutionary theory in the law); R. Peter Terrebonne, A Strictly Evolutionary M ode of Common Law, 10 J. LEGAL STUd. 397 (1981) ( borrowing tools of evolutionary analysis from biology to test the proposition that inefficient legal rules are litigated more frequently than efficient ones); Note, The In efficient Common Law, 92 YALE L.J. 862 (1983) (arguing that the accumulation of precedent under a common law system will systematically favor inefficient, rather than efficient, legal rules).

128.

[D] espite numerous technological advances in the past century, the statutory language of the Patent Act ... pertaining to patentable subject matter has not changed significantly since the inception of the Act over 200 years ago. Without current legislative guidance, courts and administrative agencies, including the U nited States Patent and Trademark Office ... have the difficult job of applying antiquated laws to cutting edge technology, resulting in a confusing legal landscape.

Christopher S. Cantzler, State Street: Leading the Way to Consistency for Patentability of Computer Software, 71 U. Co Lo. L. REV. 423, 424 ( 2000).

The statutory language used to define patentable subject matter in the United States has not changed significantly since it was first developed over 200 years ago. ... [W] Were law-making bodies do not act, courts and administrative agencies, such as the Patent and Trademark Office, are left with the difficult task of applying antiquated laws to new technologies. Often, this procedure is analogous to fitting a square peg into a round hole.... One area in which courts have been faced with unforeseen scientific advances is in the field of computer-related inventions.

Peter Weissman, Computer Softwareas PatentableSubject M atter, 23 AIPLA Q. J. 525, 527 (1995). 
The third consequence of the common law system's increasing returns feature is indeterminacy of outcome (or, as game theorists put it, multiple equilibria). Indeterminacy arises from "randomness" or unpredictability in the initial selection of the legal rule. That is not to say that the decision making process is random. Instead, randomness occurs because specific facts, circumstances, and legal arguments vary significantly from case to case. Every case that raises a new legal issue will necessarily involve a unique combination of these qualities. Moreover, cases will differ because of variation in the experiences and beliefs of the judge or judges. ${ }^{129}$

Thus, the early cases in a line of case law are unpredictable for the same reason that the first firm's decision to locate in a particular region is unpredictable: Each depends on a unique set of inherently unpredictable factors. And just as that initial unpredictable event has important consequences for the geographical location of industry, the early unpredictable cases on a legal issue have important consequences for the development of the case law on that issue. To the extent that we are unable to predict the early cases that will present a legal issue, we are equally unable to predict where these initial cases will lead. ${ }^{130}$

The conclusion that legal results are unpredictable does not mean, of course, that they are inexplicable. ${ }^{131}$ Looking backward, one may be able to trace the path of reasonable decisions that led to the current rule. Nor does the unpredictability of legal outcomes imply that they are random or that the range of possible outcomes is limitless. Rather, the possible equilibria may be highly constrained. Which of the possible equilibria will ultimately prevail depends on a number of factors, some of which are unpredictable.

One might object to the claim that there are multiple possible outcomes and argue that there is usually (or at least often) one correct result in the law. Yet the observation that the outcome is indeterminate is descriptive, not normative. That is, it may be true that there is one correct legal rule as a normative matter. But, as a descriptive matter, multiple

129. See Lewis A. Kornhauser, Symposium on Post-Chicago Law and Economics: An Economic Perspective on Stare Decisis, 65 CHI.-KENT L. REV. 63, 69-70 (1989) (suggesting that different judges may have different values, which may in turn affect their decisions).

130. Indeed, even rights now viewed as fundamental have been described by members of the Supreme Court as arising out of "historical accidents." For example, Justice Powell makes a convincing argument that the rule that jeopardy attaches in a jury trial at the moment the jury is sworn is "the product of historical accident." See Crist v. L.R. Bretz, 437 U.S. 28, 40 (1978) (Powell, J., dissenting). Similarly, the Court has held that the federal requirement of a unan imous verdict by twelve jurors was a result of historical accident. SeeWilliams v. Florida, 399 U.S. 78, 88-90 (1970) ("In short, while sometime in the 14th century the size of the jury at common law came to be fixed generally at 12 , that particular feature of the jury system appears to have been a historical accident, unrelated to the great purposes which gave rise to the jury in the first place.").

131. See Jacob S. Hacker, L earning from Defeat?: Political A nalysis and the Failu re of $\mathrm{H}$ ealth Care Reform in the United States, BRIT. J. POL. SCI. (forthcoming Jan. 2001) (discussing further the distinction between predictability and explainability). 
outcomes are almost always possible. Moreover, when it comes to cases that make it to court, the "right" legal rule is often a matter of interpretation; cases in which the result is abundantly clear generally are settled long before they arrive in the courtroom. Indeed, if the correct legal result were always clear, there would be little need for courts at all.

The well-known story of the emergence of the vexing Rule against Perpetuities provides a compelling example of the common law's increasing returns path dependence..$^{132} \mathrm{In}$ mid-seventeenth-century England, there was an ongoing battle between landowners and the courts over rules of inheritance. Landowners sought greater control over the passage of their lands, and the courts stood firm against them. In 1681, the Earl of Arundel sought to create trust indentures to prevent his land from passing to his insane eldest son. Lord Chancellor Nottingham recognized the Earl's concern as legitimate and developed a ruling to reflect his specific circumstances. The Lord Chancellor reasoned that the father could reasonably assess his living family members' capabilities and thus permitted the father's judgment to be enforced. Over the next 150 years, this ruling gradually grew into the well-known Rule against Perpetuities, under which "[n]o interest is good unless it must vest, if at all, not later than twenty-one years after some life in being at the creation of the interest." ${ }^{133}$

The development of the Rule against Perpetuities demonstrates each of the above-described properties of increasing returns path dependence in the law. First, the development of the Rule was nonergodic: A small early event-a father seeking to withhold inheritance of his land from his insane son-had a large impact on the eventual outcome. The principle that landowners should be able to decide among the persons whom they are in a position to judge in granting inheritance rights became locked into what now appears to be a peculiar standard. Second, the result was un predictable: Although we can explain quite easily how the rule developed, the final outcome would have been difficult, if not impossible, to predict in advance. Third, there is nothing inherent in the Rule against Perpetuities that leads us to believe that it was the unique equilibrium. Rather, any number of possible rules governing inheritance could have developed given a different set of historical circumstances. The famous rule, which has vexed students of property law for over a century, thus illustrates nicely the consequences of

132. This example draws from JesSE DUKEMINIER \& JAMES E. KRIER, PROPERTY 299-300 (3d ed. 1993).

133. John C. Gray, The Rule Against Perpetuities $\S 201$ (4th ed. 1942). Of course, the Rule against Perpetuities has been revoked or modified by statute in several jurisdictions. See Sanford J. Schlesinger \& Dana L. Mark, Generation-Skipping T ransfer Tax Continues to Evolve and M ay Pose Traps and Pitfalls for the Unwary, 71 N.Y. ST. B.J. 43, 49 (1999) ("The rule against perpetuities has been repealed in Alaska, Arizona, Colorado, Delaware, Iowa, Maryland, New Jersey, South Dakota and Wisconsin, and thus a trust established in any of these jurisdictions can virtually continue indefinitely."). 
increasing returns path dependence in the common law.

\section{B. EVOlutionary Path Dependence}

Of the three path dependence models discussed here, evolutionary theory has been invoked most frequently in the legal literature. Indeed, the language used to describe the common law process often draws on evolutionary metaphors. The Supreme Court has written that the "flexibility and capacity for growth and adaptation is the peculiar boast and excellence of the common law" and that "the common law is not immutable but flexible, and by its own principles adapts itself to varying conditions." ${ }^{134}$ This language reflects an underlying reality. In a common law system, the decision in each new case draws on the stock of existing precedent, and that new case forms the foundation of precedent on which future cases are based. As Justice Cardozo once explained:

The implications of a decision may in the beginning be equivocal. New cases by commentary and exposition extract the essence. At last there emerges a rule or principle which becomes a datum, a point of departure, from which new lines will be run, from which new courses will be measured. Sometimes the rule or principle is found to have been formulated too narrowly or broadly, and has to be reframed. Sometimes it is accepted as a postulate of later reasoning, its origins are forgotten, it becomes a new stock of descent, its issue unite with other strains, and persisting permeate the law. ${ }^{135}$

Evolutionary theory enjoys a long lineage in Anglo-American jurisprudence. ${ }^{136}$ It first emerged in legal literature in the nineteenthcentury German historical school of jurisprudence, which was founded in the early 1800s by Gustav von Hugo and continued by Freidrich Karl von Savigny. ${ }^{137}$ Scholars took it up with renewed vigor in the wake of the

134. Funk v. United States, 290 U.S. 371, 382-83 (1933). A federal district court similarly noted:

The genius of the common law is its flexibility and capacity for growth and adaptation. It has always been recognized that the common law is not a rigid, inflexible, static thing, but is a living organism, ever growing and expanding to meet the problems and needs of changing social and economic conditions. The common law is not a primer of rigid and absolute rules, but rather a body of broad and comprehensive principles created by judicial decisions and based on justice, reason, and common sense. Its principles have been determined by the needs of society and are ever susceptible to adaptation to new conditions, relations, and usages, as the progress of civilization may require.

Russick v. Hicks, 85 F. Supp. 281, 285-86 (W.D. Mich. 1949) (citations omitted).

135. CARDOZO, supra note 90 , at $48-49$.

136. Sesupra note6 (citing some major works on legal evolution).

137. See generally Friedrich KaRL VOn SAVIgnY, OF the Vocation of OUR Age for 
publication of Darwin's On The Origin of Species. ${ }^{138}$ In 1861, Sir Henry James Sumner Maine, for example, identified successive stages through which "progressive societies" must pass, ${ }^{139}$ and John Henry Wigmore developed a comprehensive theory of legal evolution in the early 1900 s. $^{140}$ These early works were followed by the scholarship of Oliver Wendell Holmes, who took legal evolutionary theory to the level of legal doctrine. In perhaps the most famous statement of his views on the topic, $\mathrm{H}$ olmes wrote:

The life of the law has not been logic: it has been experience. The felt necessities of time, the prevalent moral and political theories, intuitions of public policy, avowed or unconscious, even the prejudices which judges share with their fellow-men, have had a good deal more to do than the syllogism in determining the rules by which men should be governed. ${ }^{141}$

Drawing and building upon Holmes's insights, Arthur Linton Corbin ${ }^{142}$ and Robert Charles Clark ${ }^{143}$ set the stage for the economic theory of legal evolution that gained acceptance in the legal literature of the early 1970s and remains the most influential variant of legal evolutionary theory today.

LEGISLATION AND JURISPRUDENCE (1831) (exemplifying the tradition of the German historical school); 1 KonRad ZWEigert \& Hein KotZ, An InTROduction to COMPaRative LaW 144 (Tony Weir trans., Clarendon Press $2 d$ rev. ed. 1987) (1969) (same). Von Savigny's, Maine's, and Wigmore's works are examples of an early variant of legal evolutionary theory that Elliott terms "social theories of legal evolution." Elliott, Evolutionary Tradition, supra note 6, at 40. This variant is characterized by the view of the law as changing and "adapting" over time in response to changes in society, rather than as static or autonomous. It posed an alternative to the positivist conception of law and focused attention on the influence of social and cultural factors on the law. Although some of its insights continue to undergird much of modern legal evolutionary work, few modern legal scholars continue to adhere to this view of legal evolution, which is poorly defined in comparison with more modern variants of legal evolutionary theory.

138. DARWIN, supra note 7.

139. See generally SIR HeNRY JAMES SUM NER M AINE, ANCIENT LAW: ITSCONNECTION WITH THE EARLY HISTORY OFSOCIETY AND ITSRELATION TO MODERN IDEAS (1861).

140. Se generally EVolution of LAW: SeleCt ReAdings on the ORIGIN AND DeVELOPMENT OF LEGAL INSTITUTIONS (John Henry Wigmore \& Alber Kocourek eds., 1915-1918) ( 3 vols.).

141. HOLMES, THE COMMON LAW, supra note 8, at 1.

142. Arthur Linton Corbin argued in 1914 that "[a] judge's declared rules must compete for their lives with the rules declared by other judges and by all other persons. In the judicial world, as in the animal and vegetable world, the ultimate law is the law of the survival of the fittest." Arthur Linton Corbin, TheL aw and the Judges, 3 YALE REV. 234, 238 (1914).

143. Summarizing six examples of legal evolution in corporate and commercial law, Robert Charles Clark argued that in each there was a general pattern of evolution toward cost reduction. Se Robert Charles Clark, The Interdisciplinary Study of Legal Evolution, 90 YALE L.J. $1238,1241,1250-54$ (1981) [hereinafter Clark, Interdisciplinary Study] (focusing primarily on the evolution of corporate organizations and in stitutions). Clark was also the first to extend legal evolutionary theory to include statutes. Se generally Robert Charles Clark, The M orphogen esis of Subchapter C: An Essay in Statutory Evolution and Reform, 87 YALE L.J. 90 (1977); se also Robert Charles Clark, The Four Stages of Capitalism: Reflections on Investment M anagement Treatises, 94 H ARV. L. REV. 561, 561 (1981) (identifying and analyzing a "longterm pattern of changes in the institutional arrangements for aggregating and channeling capital in our private economy"). 
Modern scholars in the law and economics tradition draw on the evolutionary model to argue that competition leads to the best (most efficient) legal rule..144 In what has been termed the "classical evolutionary paradigm, ${ }^{145}$ the rule that survives the whittling process of the common law is presumptively efficient, for if it were not, it would be challenged and replaced by more efficient competitors. ${ }^{146}$ In this view, the common law evolves toward efficient rules because, inter alia, judges favor efficient rules, ${ }^{147}$ in efficient rules are litigated more often than efficient ones, ${ }^{148}$

144. For example, see William M. Landes \& RChard A. Posner, The EConomic STRUCTURE OF TORT LAW (1987) (analyzing the efficiency theory and its relationship to tort law), and infra text accompanying notes 147-50 (citing factors that law and economic scholars claim lead to the evolution of efficient common law rules). For a brief summary of this literature, see POSNER, supra note 99, at 2. One prominent exception to this tendencyamong modern scholarship is Mark Roe's article, Chaos and Evolution in Law and Economics, supra note 12 , which has caused some scholars to rethink the validity of the classical evolution-to-efficiency paradigm in describing the process of change in business and legal institutions. But Roe's work focuses primarily on the evolution of corporate structures and corporate governance and does not examine or challenge the validity of the theory in the common law context. A few other scholars have also noted instances of the panda's thumb effect in the law. Se David, supra note 12, at 19 (noting parallels between the panda's thumb effect and the development of intellectual property institutions).

145. Roe, supra note 12 , at 641 .

146. Legal scholars, of course, are far from alone in applying the evolutionary paradigm outside biology. SeeJAMESG. M ARCH \& J OHAN P. OLSEN, REDISCOVERING INSTITUTIONS 7-8, 54-56 (1989) (summarizing and critiquing social science works that advance the hypothesis that history leads to efficient rules and institutions); Richard R. Nelson, Evolutionary Theorizing About Economic Change (Apr. 13, 1993) (unpublished manuscript, on file with author) ( reviewing the use of evolutionary analysis in economics and other social sciences). Assuming that each environment produces an equilibrium that is both unique and optimal, economic, political, and sociological theorists have argued that competition for scarce resources leads to differential survival of the most optimal firms, institutions, or rules. See MARCH \& OLSEN, supra, at 54-55 (summarizing arguments of such theorists). Indeed, economists used the evolutionary paradigm to support the conclusions of neoclassical equilibrium theory as early as the 1950s. Nelson, supra, at 3. In one of the earliest examples of this work, Armen A. Alchian argued for an approach to economic theory that interpreted the economic system as an "adoptive mechanism which chooses among exploratory actions generated by the adaptive pursuit of 'success' or 'profits.'" Armen A. Alchian, Uncertainty, Evolution, and Economic Theory, $58 \mathrm{~J}$. POL. ECON . 211, 211 (1950); se also Armen A. Alchian \& Harold Demsetz, Production, Information Costs, and Economic Organization, 62 AM. ECON. REV. 777, 795 (1972) (suggesting that the firm is "a device for enchancing [sic] competition among sets of input resources as well as a device for more efficiently rewarding the in puts").

147. See POSNER, su pra note 99, at 534-36; George L. Priest, The Common Law Process and the Selection of Efficient Rules, 6 J. LEGAL STUD. 65 (1977).

148. See POSNER, supra note 99, at 559 (arguing that, due to differential rates of litigation, "over time, there will be a tendency for less efficient rules to be weeded out and replaced by efficient ones, because efficient rules are less likely to be reexamined and hence less likely, once adopted, to be discarded in the future"). Se generally Priest, supra note 147 (arguing that the joint benefits of changing the law are higher when the law is inefficient, therefore inefficient laws will be litigated more frequently than efficient laws and the common law will evolve toward efficiency); Terrebonne, supra note 127 (using the tools of evolutionary analysis to test and verify the proposition that inefficient legal rules are litigated more frequently than efficient 
litigants advocating efficient rules have greater incentives than those advocating inefficient rules to incur legal expenses that increase the likelihood of a favorable decision, ${ }^{149}$ and resorting to court settlement is more likely in cases in which the legal rules governing the dispute are inefficient. ${ }^{150}$ In essence, the model of the common law adopted by many scholars is a legal version of the Darwi nian paradigm. ${ }^{151}$

As discussed above, path dependence theory casts doubt on the claims of those who argue that the evolution of the common law leads to the most efficient legal rule. The evolution-to-efficiency argument ignores the pathdependent nature of legal change in a common law system. It fails to recognize that each choice is made within a constrained set of circumstances. A court is not always free to choose the legal rule that it believes to be the most efficient, even if it were inclined to do so. Stare decisis and its attendant rules of respect for precedent often prevent it from doing so. Just as the species in existence today are not perfect, but rather the best nature could do given the limited options left to it by history, so too are current legal rules the result of historical processes that significantly constrain the available options and, hence, the possibilities for evolution-toefficiency.

Indeed, it appears that modern scholars largely fail to notice the nuances in evolutionary theory that led Holmes to some of his most intriguing insights. Holmes not only drew explicit comparisons between

ones). But sæg generally N ote, supra note 127 (arguing that more "reckless" rules are more likely to be litigated and thus more likely to develop precedent favorable to their replication, thereby squeezing out less reckless rules). Robert Cooter and Lewis Kornhauser offer a corrective to the selective litigation theory. They assume that inefficient rules are selectively relitigated but that judges have no insight into which rules are better. They conclude that under these circumstances the evolutionary forces in the law will not lead to a single efficient rule, but instead to an "equilibrium" in which both the best and worst legal rules will recur. Se Cooter \& Kornhauser, supra note 127 ( discussing the "impossibility theorem"); sæe al so Robert D. Cooter \& Daniel L. Rubinfeld, Economic Analysis of Legal Disputes and Their Resolution, 27 J. ECON. LIT. 1067, 1092 (1989) ("Does litigation tend to select inefficient laws? Theory suggests a weak 'Yes.'").

149. See generally John C. Goodman, An Economic Theory of the Evolution of Common Law, 7 J. LEGAL STUD. 393 (1978) (arguing that even if the likelihood of litigation of efficient and inefficient rules is similar, the legal system will contain more efficient laws than inefficient laws because parties who stand to benefit from an efficient rule will invest more in litigation - and will consequently have a higher probability of winning-than do those who favor an inefficient rule).

150. See generally Paul Rubin, Why is the Common Law Efficient, 6 J. LEGAL STUD. 51 (1977). But see Cooter \& Kornhauser, su pra note 127, at 145 (arguing that evolutionary pressures arising from settlement decisions by litigants "are insufficient to cause the legal system to adopt and retain the best legal rule without the help of judges"); (f. Cooter \& Rubinfeld, supra note 148, at 1089-91 (offering a corrective to the "early studies" suggesting that settlement incentives lead to efficient le gal rules, but affirming their basic conclusion that differential settlement incentives can generate efficient legal rules).

151. See Clark, Interdisciplinary Study, su pra note 143, at 1241 (suggesting that the process of legal change might be analogized to "Darwin's natural-selection view of the origin of species"). 
biological and legal evolution, but he also noted their tendency to retain vestiges of the past. Holmes wrote, "[J] ust as the clavicle in the cat only tells of the existence of some earlier creature to which a collar-bone was useful, precedents survive in the law long after the use they once served is at an end and the reason for them has been forgotten." ${ }^{152} \mathrm{He}$ was critical of rules that persist "for no better reason ... than that... [ [they were] laid down in the time of Henry IV," and even more critical of a rule "the grounds upon which it was laid down have vanished long since, and [ which] simply persists from blind imitation of the past." ${ }^{153}$ When rules are followed only because of tradition, he argued, irrational law may result. ${ }^{154}$ Thus the venerable Holmes, to whose work modern legal evolutionary literature can be traced, observed that legal evolution-far from always leading to efficient outcomes-may instead lead to inefficient and irrational results when legal precedent or tradition holds sway.

As Holmes's observations indicate, not only are the claims of evolutionto-efficiency in the common law inaccurate as a descriptive matter, but they are also based on a misunderstanding of evolutionary theory. Traditional evolutionary theory does not support the teleology often ascribed to it. The claim that the "fittest" will survive the natural selection process does not suggest that they are objectively "perfect."155 Rather, "survival of the fittest" simply indicates that natural selection favors those animals that are most succesful at reproducing in a given environment (which of course requires that they possess qualities that allow them not only to reproduce successfully but also to survive to an age at which they can reproduce). If a characteristic neither aids nor hinders reproductive success, then it may remain or disappear with no consequence. Moreover, imperfect characteristics that work reasonably well, like the panda's thumb, may survive the process of natural selection. Therefore, the outcome of natural selection is not perfection, but is instead a series of progressive adaptations that lead to differential reproductive success. This is as much true in the law as in biology: Legal equivalents of the imperfect panda's thumb-vestiges of a legal rule's past-remain throughout the legal system.

Scholars in the new institutionalism genre of political science examine the way in which political institutions evolve over time. They have concluded that the common claim that historical processes lead inexorably toward efficiency is faulty, both empirically and theoretically. ${ }^{156}$ They point out that

152. HOLMES, THE COMMON LAW, supra note 8 , at 35.

153. HOLMES, The Path of the Law, supra note 1, at 187.

154. Id. at 187-94.

155. Se supra notes $56-60$ and accompanying text (elaborating on the argument that biological evolution does not lead to a perfect outcome).

156. The "new institutionalism" or "historical institutionalism" literature argues that political struggles "are mediated by the institutional setting in which [they] take place." G. John Ikenberry, Conclusion: An Institutional Approach to American Foreign Economic Policy, in THE STATE 
extensive periods of adjustment may be required during which "diverse, conflicting, and inefficient solutions survive." ${ }^{157}$ An equilibrium-a single efficient outcome-may not exist. Even if one does exist, the adaptive rate of historical processes may proceed more slowly than changes in the environment, leading to a perpetual lag and, therefore, perpetual disparity between the institution or rule and its environment. Institutions are often resistant to change: They embed routines in a structure, develop their own criteria of appropriateness and success, and socialize existing arrangements. ${ }^{158}$

The same phenomenon occurs in the law. When the rate of change in the legal environment outpaces the adaptation of legal rules, equilibrium is unlikely to be achieved before the environment changes. Because the legal environment is no more stable or static than the biological or political one, there will often be some degree of mismatch between the legal rule and the environment in which it is applied. This "mismatch" between the rate of adaptation and the rate of change in the environment is perhaps even more pronounced in legal institutions than in any other institution. The rule of stare decisis and the life tenure of most judges are, in fact, designed to embed resistance to change in the common law system. Indeed, many legal scholars celebrate this very quality of the legal system. Bruce Ackerman, for example, argues that the courts serve an essential "preservationist function ... protecting the hard-won principles of a mobilized citizenry against erosion by political elites who have failed to gain broad and deep popular support for their innovations." 159 The law's failure to adapt quickly may lead to inefficiency, but it also protects against instability and immediate surrender to momentary and ill-conceived whims of the public. This is where the biological and legal analogies diverge perhaps most significantly: Animals are largely powerless to preserve themselves in the face of marked changes in their environment, but judges, litigants, and institutions are capable of perpetuating legal rules long after the conditions that gave rise to them disappear.

New evolutionary theory also offers some useful insights into the pathdependent nature of the common law. As with the evolution of species, the

And American Foreign ECONomic Policy 222-23 (G. John Ikenberry et al. eds., 1988). It "stresses that many of the contemporary implications of . . . temporal processes are embedded in institutions- whether these be formal rules, policy structures, or norms." Paul Pierson, The Path to European Integration: A H istorical Institutionalist Analysis, 29 COMP. POL. STUD. 123, 126 (1996). For more on the emergence of "new institutionalism," see Ira Katz Nelson, H istorical Institutionalism in Comparative Politics, in STRUCTURING POLITICS: HISTORICAL INSTITUTIONALISM in COMPARATIVE ANALYSIS 1-32 (Sven Steinmo \& Kathleen Thelen eds., 1992) .

157. M ARCH \& OLSEN, supra note 146 , at 55.

158. For example, the positions of political parties may change more slowly than voter preferences, thus rendering equilibrium between voter preferences and party position impossible to achieve. Id.

159. 1 ACKERMAN, supra note3, at 10. 
evolution of the common law occurs sporadically. Long periods of stasis are followed by rapid change. The rapid change, or "punctuation," can be brought about by a number of sources: higher court opinions that overrule or significantly alter existing legal rules; reconsideration of legal rules by the courts in which they were first established; new legislation; introduction of a novel legal issue; or, on rare occasions, constitutional amendments. ${ }^{160}$ For example, in perhaps the most common "punctuation" in the common law, a line of cases develops in a lower court, coalescing around a particular resolution of a legal issue. When a case from that line is appealed to the next higher court, however, the higher court may either adopt the lower court's resolution of the legal issue, modify it, or reject it entirely. The review of the case by the higher court is therefore a punctuation in the legal model, just as an alteration in environmental conditions is a punctuation in the biological model. As in the biological sphere, the punctuation-the imposition of a new or modified resolution of a legal issue-is followed by a period of equilibrium during which courts follow the new legal rule, exploring its bounds and applying it to new circumstances but remaining true to its central requirements.

Unlike biological evolution, legal evolution is not always constrained to draw on the existing stock of material during periods of rapid change. A higher court may create a new legal rule that departs significantly from the past rule, though it will remain constrained to some extent by its own precedents and by the decisions of any higher court. In this sense, legal evolution bears more similarity to political and institutional change as described by the "critical junctures" model, ${ }^{161}$ which focuses on periods of state-building crisis during which there is rapid change in political and institutional arrangements. ${ }^{162}$ The literature on critical junctures varies

160. Bruce Ackerman's "constitutional moments"-the Founding, Reconstruction, and the New Deal-stand as good examples of such punctuations: points in time when the law has undergone rapid and significant change, leading to a fundamental shift in the path of the law. See id.

161. Although the majority of the work focusing on critical junctures does not draw explicit comparisons to the biological literature, Stephen Krasner has pointed out that the model nonetheless bears striking resemblance to the punctuated equilibria model of biological change. Institutions are characterized by periods of stability that are periodically "punctuated" by periods of rapid change - critical historical junctures - after which a new set of arrangements set in that govern a new period of stability. In Krasner's account, the causes of the periods of rapid change are exogenous, emanating from changes in the external environment. Like biological entities, historically evolved institutions are "sticky"--they tend to resist change until an external crisis requires it. And as in the biological model of punctuated equilibiria, in which future evolutionary developments are constrained by the gene pool produced by periods of rapid adaptation, the solution chosen or path taken during the state-building crisis or critical juncture "canalizes future developments." Krasner, supra note 45, at 223, 240.

162. See, e.g., Ruth Berins Collier \& David Collier, Shaping the Political arena: CRitical Junctures, The Labor Movement, AND Regime Dynamics in LATIN AMERICA 27-39 (1991) (reviewing the critical junctures framework); Jacob S. Hacker, The H istorical Logic of $\mathrm{N}$ ational $\mathrm{H}$ ealth Insurance: Structure and Sequence in the Development of British, Canadian, and U.S. 
greatly, but the works in this vein all share the view of institutional change as occurring in a burst (a critical juncture) followed by a period of relative stability. N ew arrangements achieved during the critical juncture shapes the period of stability that follows in important ways. Each critical juncture, in other words, produces a distinct legacy that remains largely intact until the next critical juncture breaks down and reshapes the political and institutional arrangements anew. ${ }^{163}$

The environment and, to some extent, chance mutations shape periods of change in biological evolution. Volitional action plays no role in determining the direction of the change that occurs during these punctuations. In political, institutional, and legal evolution, however, conscious human agency shapes the periods of change. Of course, history constrains the range of options even during these periods of relative freedom. In the legal context, for example, existing rules shape litigants' arguments and the law as it has evolved shapes the issues presented by a case. Therefore, higher courts may be reluctant to stray far from the rules constructed by lower courts despite their freedom to do so. Nonetheless, there remains a wider array of options and a greater degree of freedom to shape the options selected than in the biological context.

Despite these substantial differences between the biological and legal context, the biological model of stasis punctuated by periods of rapid change provides useful lens on the process of legal evolution in a common law system. It indicates the central importance of the brief but crucial punctuations that open up windows of opportunity for sweeping change. Unlike biological evolution, these windows offer opportunities for human agency to shape the legacy that will follow. Once the windows close, however, a new period of stasis settles in, making significant change extremely difficult. If the opportunities for significant change in law occur

M edical Policy, 12 Stud. AM. PoL. Dev. 57, 77-80 (1998) (providing a brief overview of the critical junctures model); Krasner, supra note 45 , at 240-44 (reviewing and summarizing critical junctures literature and drawing analogies between it and the punctuated equilibrium paradigm); Kathleen Thelen, Historical Institutionalism in Comparative Politics 29-37 (1998) (unpublished manuscript, on file with author) (reviewing political science literature that engages in historical institutional analyses of critical junctures). The term "critical junctures" was first used in this context in Seymour Martin Lipset \& Stein Rokkan, CleavageStructures, Party Systems, and Voter Alignments: An Introduction, in PARTY SYSTEM AND Voter ALIGNMENTS: CrossNATIONAl PeRSPECTIVES 1, 37 (Seymour Martin Lipset \& Stein Rokkan eds., 1967).

163. See, e.g., COLLIER \& COLLIER, supra note 162, at 29 (discussing a framework for analyzing critical junctures). Also referred to by Sidney Verba and others as the "branching tree model of sequential development," he critical junctures approach suggests that the choice made during a juncture forecloses other options because vested interests arise around the solution chosen and operate to defend and maintain it until a new crisis once again opens the door to substantial change. Sidney Verba, Sequences and Development, in CRISES AND SEQUENCES IN Political DeVelopment 283, 308 (1971); see also Krasner, supra note 45, at 240. As in other models of path dependence, "[p] ast choices preclude certain strategies and make them very costly." Id. 
only in certain specified circumstances, such as when an issue is appealed for the first time to a higher court or when a novel legal issue is raised in court, then advocates of legal change will be most effective in achieving their goals if they focus their energies on these circumstances. Moreover, in law, perhaps more than in any other sphere in which the model of punctuated equilibrium is apparent, participants in the system can use their understanding of this model of change to incite "punctuations." Participants can create opportunities for significant change by, for example, raising a new legal issue or appealing an issue to a higher court. Indeed, it is also possible for participants to prevent such periods of rapid change from occurring by, for example, settling out of court. ${ }^{164}$

The claim that significant change is only possible during punctuations does not imply that the law remains entirely static during periods of stasis. As in the biological model, the periods between punctuations are characterized by gradual change. In biological reproduction, each new generation possesses some new combination of characteristics that is different from previous generations. This is perhaps even more true in law: Each new generation of cases presents a new set of facts and circumstances to which an earlier-developed legal rule must be applied. Because the facts of the new cases are always different in some respects from those of the cases that preceded them, the rule must always be expanded or modified in order for the cases to be resolved.

One final example illustrates many of the characteristics of evolutionary path dependence in the law. The process of path-dependent evolution in the law is evident in the development of the "inherently dangerous" rule, which Dean Levi and many others have used to illustrate the movement of legal concepts in case law over time. ${ }^{165}$ The "inherently dangerous" rule has

164. The famous Piscataway case is a good example of this. The Supreme Court dismissed certiorari in the much-anticipated affirmative action case, Piscataway T own ship Board of Education v. Taxman, 522 U.S. 1010 (1997), after a coalition of leading civil rights groups not directly involved in the case but concerned about a Supreme Court decision on affirmative action agreed to provide the major share of a $\$ 433,500$ settlement payment to the plaintiff in the case. See Taxman v. Bd. of Educ., 91 F.3d 1547, 1550 (3d Cir. 1996), cert. granted sub nom. Piscataway Township Bd. of Educ. v. Taxman, 512 U.S. 1117 (1997), and cert. dismissed, 522 U.S. 1010 (1997) (holding that defendants' affirmative action policy violates Title VII because it does not have a purpose equivalent to that of Title VII and because it unnecessarily burdens non minority interests); Linda Greenhouse, Settlement Ends H igh Court Case on Preferences: Tactical Retreat, N.Y. TIMES, Nov. 22, 1997, at A6 (discussing T axman and the settlement that ensued).

165. See E. Levi, Introduction, supra note 95 , at $507 \&$ n.12 (discussing the breakdown of the "inherently dangerous" rule). Indeed, Levi's three theorized stages of development of legal concepts match the critical junctures framework almost perfectly. He explains:

The first stage is the creation of the legal concept which is built up as cases are compared. ... The second stage is the period when the concept is more or less fixed, although reasoning by example continues to classify items inside and out of the concept. The third stage is the breakdown of the concept, as reasoning by example has moved so far ahead as to make it clear that the suggestive influence of 
its origins in the case of Dixon v. Bell, ${ }^{166}$ which represents a punctuation in the case law. In Dixon, the court held the owner of a gun liable for the accidental shooting of the plaintiff's son by a servant girl whom the owner had sent to fetch the gun. The judge in the case described the gun as "left in a state capable of doing mischief," thus establishing the new legal principle that owners could be held liable for harm done by commodities due to a lack of care. ${ }^{167}$ From this introduction, courts gradually expanded the "inherently dangerous" rule to give it force far outside its original application. The principle first articulated in Dixon became encapsulated in a doctrine, announced in Longmeid $v$. Holliday, ${ }^{168}$ that permitted recovery when harm was caused by "things in their nature dangerous," but not when harm was caused "by an unknown latent defect," such as a defective lamp. ${ }^{169}$

The case law then settled into what Levi characterizes as the "second stage" of development in a legal rule, during which "the concept is more or less fixed, although reasoning by example continues to classify items inside and out of the concept." 170 This period of stasis is characterized by the unquestioned application of the legal rule announced in Longmeid. Although the case law remained consistent with the original insights of Dixon and the legal concept it spawned, it was far from static. Courts necessarily applied the rule to new and unforeseen circumstances.

The case law then entered the final stage of development-a new punctuation, during which the legal concept broke down, "as reasoning by example... moved so far ahead as to make it clear that the suggestive influence of the word is no longer desired."171 This period began with a new seminal case, MacPherson v. Buick, ${ }^{172}$ in which the New York Court of Appeals found the Buick Motor Company liable for injuries caused by a defective wheel. In its holding, the court broke down the distinction between things "inherently dangerous" and those "latently dangerous," and, in doing so, "renamed and enlarged the danger category" and "brought the law into line with 'social considerations.'"173 This new punctuation thus set the stage for a new cycle of legal evolution.

\section{Sequencing Path Dependence}

The important additional insight offered by applying sequencing path

the word isno longer desired.

Id. at 506 .

166. 5 Maule \& Selwyn 198 (1816), cited in E. Levi, Introduction, supra note 95, at 507 \& n.14.

167. E. Levi, Introduction, supra note 95 , at 508 (citation omitted).

168. 115 Eng. Rep. 752 (1851).

169. E. Levi, Introduction, supra note 95 , at 510.

170. Id. at 506 .

171. Id.

172. 111 N.E. 1050 (N.Y. 1916).

173. E. Levi, Introduction, supra note 95, at 517. 
dependence to the courts is simple yet arresting: The order in which cases are presented to the courts will have a significant influence on the legal rule selected. ${ }^{174}$ This influence will be greater if judges do not engage in sophisticated voting ${ }^{175}$ - that is, looking forward and reasoning backward from the ultimate result to determine the best course of action at each juncture. Yet it will still exist if they do. Even if judges are able to act as sophisticated voters, game theory and social choice theory tell us that the agenda will nonetheless influence the outcome. Although a result outside the Condorcet set cannot be achieved under a system of sophisticated voting, the agenda will still influence which point within the Condorcet set is selected.

Repeated cycling, of course, is unlikely to occur in a legal system that relies upon precedent. Where group preferences are intransitive, stare decisis will advantage the status quo, thereby retarding a cycle that might otherwise occur. This is an important distinction between political and legal decision making: The rule of stare decisis that applies in a common law system reduces the likelihood that a voting cycle will occur. ${ }^{176}$

A simple hypothetical example helps illustrate these points. Imagine that there is a group of civil rights activists who wish to move from a standard of rational basis scrutiny for gender discrimination to strict scrutiny. Assume three kinds of judges (and assume equal numbers of judges in each category): (I) activists who prefer strict scrutiny to intermediate scrutiny, and intermediate scrutiny to rational basis; (II) cautious reformers who prefer intermediate scrutiny to rational basis, but feel that a move to strict scrutiny would be too radical a change and thus prefer the existing rational basis standard to strict scrutiny; (III) conservatives who prefer the existing rational basis standard to the other alternatives, but who prefer strict

174. I am interested here in one particular application of game theory to the common law, which I term sequential path dependence. The multitude of other applications of game theory to the legal process are beyond the scope of this Article. Indeed, even when discussingthe phenomenon of agenda setting, I have in mind only the question of the order in which a court considers cases. I do not, for instance, include here any analysis or discussion of the possible manipulation of the agenda by judges to influence the outcome of particular cases once they arrive on a court's docket. This and other inquiries suggested by game theory are outside the scope of this Article. Notably, Judge Easterbrook has likewise observed the applicability of social choice theory to the common law system, though he has limited his observations to the Supreme Court context. See gen erally Easterbrook, supra note 102. See also Maxwell L. Stearns, Standing Back From the Forest: Justiciability and Social Choice, 83 CAL. L. REV. 1309, 1318 (1995) (outlining "the evolution of modern standing and provid[ing] a functional analysis of that doctrine based upon social choice theory").

175. See supra text accompanying notes $79-84$ (explaining that sophisticated voting precludes an outcome that falls outside the Condorcet set).

176. Of course, political institutions embody other rules and procedures, such as supermajority requirements and committees with exclusive jurisdiction, that also serve to retard cycling. Se KeIth Kreihbel, Nformation and Legislative Organization 27-28 (1991) (summarizing "new institutional" literature proposing solutions to the cycling or "chaos" problem embodied in political institutions). 
scrutiny to intermediate scrutiny because they oppose the creation of a new standard of intermediate scrutiny. Civil rights lawyers can bring two cases in succession. They would like to achieve strict scrutiny. If they can guess the preferences of the court members, clearly they will not seek strict scrutiny in the first case. Instead, they will first seek intermediate scrutiny. Intermediate scrutiny will prevail over the rational basis standard (with type I and type II judges voting in its favor and type III judges voting against). The litigants will then bring a case seeking strict scrutiny. Strict scrutiny will prevail over the intermediate scrutiny standard (with type I and type III judges voting in its favor and type II judges voting against). In this example, the order in which the cases are brought determines the outcome. Moreover, note that the introduction of the intermediate scrutiny option also alters the outcome. Were the court faced with a simple choice between strict scrutiny and rational basis, rational basis would prevail. ${ }^{177}$

The insight that the order in which a case arrives at a court may determine its outcome focuses attention on the agenda with which a court is presented. For the most part, courts have little control over which cases appear before them and in what order. To the extent, then, that outcomes depend on the ordering of cases, there is room for strategic manipulation of courts' agendas to obtain desired ou tcomes.

The conclusion that the agenda-the order in which decisions are made-in a common law system can influence the outcome of a case, or, indeed, a line of cases, has different implications for different courts. Who holds the agenda-setting power depends directly on the extent of a court's farsightedness and control over its docket. Courts that possess discretionary jurisdiction, particularly the U.S. Supreme Court and many state supreme courts, are better able to control the order in which they consider pressing legal issues. Yet even the U.S. Supreme Court, which possesses almost singular control over its docket, has little power over which cases appear in the pool of cases considered for review. ${ }^{178}$ In general, appellate courts possess greater foresight than trial courts in identifying cases that may come before them because they can observe cases in the trial courts that may eventually work their way onto their dockets. Trial courts do not have this luxury and are therefore rarely able to predict what cases may be presented.

The element of agency in the selection of cases introduces interesting

177. This scenario violates one of the fairness conditions of Arrow's theorem known as the independence of irrelevant alternatives: "a property of a social choice function such that, if two preference profiles are identical with respect to some subset of alternatives, then the social choice from each profile is the same from that subset." RIKER, supra note 61, at 294-95. Of course, that is precisely the point of Arrow's theorem: "no method of amalgamating individual judgments can simultaneously satisfy some reasonable conditions of fairness on the method and a conclusion of logicality on the result." Id. at 116.

178. Occasionally, a Justice may encourage an appeal of a particular issue to the Court by suggesting in a dissent from denial of certiorari or in an opinion that a particular issue is ripe for review. PERRY, supra note 108, at 212-15. 
wrinkles into the examination of sequencing path dependence. What power litigants lose in determining the order in which issues are presented to a court, the court itself gains. And some members of a court may gain more than others. At the U.S. Supreme Court, for instance, Chief Justice Rehnquist circulates what is called the "discuss list"-a list of cases that he deems potentially "certworthy" - in advance of every conference at which the Justices consider certiorari petitions. ${ }^{179}$ Although any Justice may add a case to the discuss list with a simple request, the Chief Justice's power to set the initial agenda still influences the outcome. It allows the Chief Justice to suggest a set of certworthy cases and thus create a presumption that cases not on the list are not worthy of the Court's consideration. Moreover, it is likely that a Justice who adds a case to the discuss list feels compelled to argue in favor of granting certiorari for the case, thus leading Justices only to add cases in which they are willing to actively advocate granting certiorari. Indeed, each Justice takes responsibility for leading the discussion at conference (if there is any) for any case that he or she places on the discuss list. ${ }^{180}$ Because no Justice is likely to take on this responsibility lightly, the Chief Justice's power to issue the initial discuss list places a great deal of the agenda-setting power in his hands.

In addition, the Chief Justice obtains some additional agenda-setting power through the Supreme Court Conference, at which the Justices discuss their views and take initial votes on recently argued cases. At the Conference, the Justices present their views on each case in order of seniority, beginning with the Chief Justice. ${ }^{181}$ As the first speaker, the Chief Justice is able to frame the discussion that follows. The Chief Justice thus has the power to add alternatives for the other Justices to consider (for example, by raising the possibility of dismissing a case as improvidently granted or putting forward a jurisdictional concern) and may thereby alter the holding of the case, much as adding the option of intermediate scrutiny altered the outcome of the hypothetical example above.

The central insight offered by sequencing path dependence- that the ordering of cases can influence outcomes-is related, but not identical, to the claim of increasing returns path dependence theory that the common law exhibits nonergodicity. As was discussed above, a consequence of the common law's increasing returns path dependence is that the early cases to raise a legal issue will have dramatic influence over future decisions. Moreover, small statements in early opinions may be broadened and magnified over time, gaining importance and influence as they grow. Sequencing theory further refines these insights into how the pathdependent nature of the common law can influence outcomes. N ot only do

179. See id. at 85-89 (describing the discuss list procedure).

180. Id. at 86 .

181. Id. at 43-44. 
small, early events have increasing effect over time, but the order in which the alternatives are presented may have profound influence on the ultimate outcome.

This is a phenomenon that experienced litigators have long understood, even if they have not had a label or a clear explanation for it. This understanding is evident in their efforts to construct lines of case law that lead the courts down a path toward the desired result. Perhaps the most well-known and celebrated example of this is Justice Thurgood Marshall's careful effort during his years litigating on behalf of the NAACP to erode the "separate but equal" rule of Plessy v. Ferguson. ${ }^{182}$ Justice Marshall and his colleagues, knowing that the Supreme Court would be extremely reluctant to declare the "separate but equal" rule unconstitutional, executed a series of well-planned steps designed to lead the Court gradually in that direction. They determined that the key to ending legal segregation was to challenge three aspects of segregated education: "that state law required separate schools, that expenditures were unequal, and that there were no mechanisms under state law to make expenditures equal." 183 But rather than challenge the segregation of all public education immediately, they decided to begin the sequence of cases with a challenge to segregation by a law school, ${ }^{184}$ where they believed their chance of success in court was greatest. ${ }^{185}$ They gradually built on their early successes, eventually setting the stage for the revolutionary case of Brown v. Board of Education. ${ }^{186}$ Justice Ruth Bader Ginsburg adopted a similar strategy in her efforts to increase the Court's standard of scrutiny in gender discrimination cases. She engaged in a meticulously calculated case sequence including Red v. Reed, ${ }^{187}$ Frontiero v.

182. 163 U.S. 537 ( 1896)

183. MaRk V. TUSHnet, MAKing CiVIL Rights LaW: Thurgood Marshall and the SUPREME COURT, 1936-1961, at 12-13 (1994).

184. Se generally MCLaurin v. Okla. State Regents, 339 U.S. 637 (1950) (prohibiting the University of O klahoma from requiring a black graduate student to sit physically separated in the classroom, to use separate tables outside the library, and to eat at separate times in the school cafeteria); Sweatt v. Painter, 339 U .S. 629 (1950) (requiring admission of qualified black students to the University of Texas Law School); Sipuel v. Bd. of Regents, 332 U.S. 631 (1948) (requiring Oklahoma to provide an equal law school education to a woman denied admission to the U niversity of Oklahoma because she was black); Mo. ex rel. Gaines v. Canada, 305 U.S. 337 (1938) (ordering the State of Missouri to either admit blacks to the existing white law school or to provide an in-state law school for blacks) ; Pearson v. Murray, 182 A. 590 ( Md. 1936) ( finding unconstitutional the denial of admission to Maryland Law School to a black man on the basis of his race).

185. TUSHNET, supra note 183 , at 13.

186. 347 U.S. 483 (1954). For a more thorough discussion of the NAACP's history in this respect, see Roger L. Goldman \& DAVID Gallen, ThuRgood MARSHALl: JUSTICE FOR ALL (1992); TUSHNET, supra note 183; M ARK V. TUSHNET, THE NAACP'S LEGAL STRATEGYAGAINST Segregated Education, 1925-1950 (1987); JuAn Williams, THuRgood MARSHALL: AMERICAN REVOLUTIONARY (1998).

187. 404 U.S. 71 (1971) (striking down a state statute that designated preference to males over females in administering the estate of a person that dies intestate when both are in the 
Richardson, ${ }^{188}$ and Craig v. Boren, ${ }^{189}$ that led the Court down a path from the traditional rational basis test toward stricter scrutiny in gender-bias cases. ${ }^{190}$ Of course, unlike the hypothetical example above, she was unable ultimately to persuade the Court to adopt the strict scrutiny standard.

In these examples, the effects of increasing returns and sequencing path dependence are interwoven. Increasing returns path dependence helps explain why Justices Marshall and Ginsburg formed litigation strategies that

same entitlement class). Justice Ginsburg used the principle of equal protection normally reserved for race discrimination cases to argue for the application of heightened scrutiny in gender discrimination cases. The Court did not abandon its rational basis test but it held that the gender classification at issue, which had passed the rational basis test below, was invalid because "[a] classification 'must be reasonable, not arbitrary, and must rest upon some ground of difference having a fair and substantial relation to the object of the legislation, so that all persons similarly circumstanced shall be treated alike.'" I d. at 76 (quoting Royster Guano Co. v. Virginia, 253 U.S. 412, 415 (1920)).

188. 411 U.S. 677 ( 1973) (holding that federal statutes requiring uniformed servicewomen to prove that their husbands are dependent upon them for more than half of their support in order to obtain "dependent" status entitling them to increased quarters, allowances and health benefits violates due process where uniformed servicemen did not have to make a similar showing in order to obtain "dependent" status for their wives). Justice Ginsburg sought to build on the decision in Reed by advocating a heightened standard of scrutiny for gender-based classifications. A plurality of the Court adopted the strict scrutiny standard advocated by Justice Ginsburg, id. at 688, while four Justices concurring in the judgment refused to extend the test beyond that articulated in Ræd. The remaining Justice, Justice Rehnquist, dissented. Id. at 691 (Rehnquist, J., dissenting).

189. 429 U.S. 190 (1976) (holding that a state statute making it illegal to sell $3.2 \%$ beer to males under the age of 21 while allowing the sale of beer to females over the age of 18 violates the equal protection guarantees of the Constitution). Justice Ginsburg, relying on Red and Frontiero, advocated a new standard for gender classification - "intermediate scrutiny" - which the Court adopted.

190. See gen erally Joyce Ann Baugh et al., Justice Ruth Bader Ginsburg: A Preliminary Assessment, 26 U. TOL. L. REv. 1 (1994) (examining Justice Ginsburg's votes during her first term on the Supreme Court); Deborah L. Markowitz, In Pursuit of Equality: One Woman's Work to Change the L a w, 14 WOMEN'S RTS. L. REP. 335 (1992) (detailing Justice Ginsburg's work as a litigator that strategically, in a series of incremental steps, moved the Court's analysis of sex discrimination from rational basis to intermediate scrutiny); Carol Pressman, TheH ouse That R uth Built: Justice Ruth Bader Ginsburg, Gender and Justice, 14 N.Y.L. SCH. J. Hum. RTS. 311 (1997) (examining J ustice Ginsburg's impact on sex discrimination law); Scott M. Smiler, JusticeR uth Bader Ginsburg and the Virginia M ilitary Institute A Culmination of Strategic Success, 4 CARDOZO WOMEN'S L.J. 541 (1998) (describing Justice Ginsburg's efforts, as a litigator and from the bench, to persuade the Court to move closer to a strict scrutiny test for gender-related discrimination); Sheila M. Smith, Justice Ruth Bader Ginsburg and Sexual H arassment Law: Will the Second Female Supreme Court Justice Become the Court's First Women's Rights Champion?, 63 U . CN. L. REv. 1893 (1995) (analyzing Justice Ginsburg's work as a litigator in sex discrimination cases and considering how her presence on the Supreme Court could affect sexual harassment law). After Frontiero, but before Craig, Justice Ginsburg litigated Kahn v. Shevin, 416 U.S. 351 (1974), yet another gender discrimination case. Justice Ginsburg became involved in the case, which she believed to be a poor one, in an effort to minimize the damage that the case (which had been filed by a local ACLU affiliate) might do to her efforts to lead the Court to a heightened standard of review. Although she lost the case, she succeeded in persuading the Court not to overrule the path of precedents she had carefully constructed. SeM arkowitz, supra, at 346-48. 
sought to move the Court in incremental steps toward their desired goals. Sequencing path dependence adds to this a recognition that they used their agenda-setting power to present cases in an order that maximized their chances of obtaining the legal standard they sought.

This illustrates an important point with which I will conclude my discussion of path dependence theory's application to the law: The three types of path dependence described above are not mutually exclusive or inconsistent with one another. Rather, the three types of path dependence operate in tandem in a common law legal system. While one type of path dependence may have greater influence in a certain area of law or at a particular point in time, the operation of one type does not preclude the operation of the others. Thus, increasing returns path dependence may push the development of a line of cases further in the direction already begun, even if it is no longer the most efficient. At the same time, the evolution of the same legal rule may be outpaced by changes in the environment. This is by no means inconsistent with the prediction that the order in which cases are presented affects the outcome, perhaps leading to a result that is not Pareto-optimal. Thus, the three types of path dependence are separate, but overlapping, facets of the process of legal change in a common law legal system.

\section{CONSEQUENCES OF PATH DEPENDENCE THEORY For THE DOCTRINE OF STARE DECISIS}

The application of path dependence theory to the common law leads, as this Article demonstrates, to some important insights: Legal change is unpredictable ex ante and nonergotic, and early outcomes may become locked in. The law evolves gradually over time, drawing on an existing stock of precedent, punctuated by periods of rapid adaptation. And ultimate legal outcomes depend significantly on the order in which decisions are made. These insights lead to several conclusions: The lessons for litigants, particularly those seeking broad legal change, are clear. Opportunities for obtaining significant legal change are limited. Litigants seeking a significant impact on the law should seek out (or attempt to create) punctuations, for it is only during punctuations that major change is possible. ${ }^{191}$ They must also be aware of the crucial importance of early decisions, which lock the law into

191. The conclusion that legal results are unpredictable does not in any way suggest that efforts to alter the path of the law are futile. Indeed, part of what makes legal outcomes un predictable is the very fact that crucial moments in the path of the law are very much subject to influence by relatively small factors. A persuasive argument by a litigant that raises a novel legal issue may persuade a court to decide a case differently than it might otherwise have done; a carefully planned sequence of cases from a legal advocacy group may lead a court down a path to a result that it otherwise would not have chosen; or a legislature may intervene to reverse the course of the law in an area that it has previously ignored. It is preciselybecause these types of interventions are so influential in shaping the course of the law that the course of the law cannot be predicted in advance. 
a distinct path from which it is difficult to diverge thereafter. And they should consider the sequence in which they bring legal issues to the courts and cultivate, when possible, a sequence of cases calculated to move the courts gradually in the desired direction.

These are the clear lessons for advocates of legal change. The insights of path dependence theory also lead to conclusions regarding the proper treatment of precedent in the legal system. If the common law process as governed by the doctrine of stare decisis is path-dependent, and if path dependence can lead to outcomes that are deeply influenced, for instance, by small early decisions and the order in which cases are decided, then was $\mathrm{H}$ olmes correct when he argued that we should place limits on the reliance upon precedent? ${ }^{192}$

Before reaching a conclusion on the proper place of stare decisis, it is first necessary to consider the doctrine's many benefits. The arguments in favor of stare decisis fall into two broad categories: instrumental and intrinsic. Instrumentalists argue that the use of precedent contributes to greater predictability and certainty in the law. ${ }^{193}$ By creating a predictable set of legal rules that structure interactions, such as contracts and business deals, precedent also encourages beneficial reliance, allowing businesses to

192.

It is revolting to have no better reason for a rule of law than that so it was laid down in the time of Henry IV. It is still more revolting if the grounds upon which it was laid down have vanished long since, and the rule simply persists from blind imitation of the past.

HOLMES, T he Path of the Law, supra note 1, at 187.

193. See Oliver Wendell Holmes, Holdsworth's English Law, in Collected Legal PaPers 285, 290 (1920) ("II]mitation of the past, until we have a clear reason for a change, no more needs justification than appetite. It is a form of the inevitable to be accepted until we have a clear vision of what different thing we want."); WASSERSTROM, supra note 106, at 60 ("The reason that undoubtedly is most often cited as constituting a justification for the doctrine of precedent is that its consistent application assures to the legal system a degree of certainty which would otherwise be impossible to attain."); David Lyons, Formal Justice and Judicial Precedent, 38 VAND. L. REV. 495, 496 (1985) ("The reason most often given for the practice of precedent is that it increases the predictability of judicial decisions."); Maltz, supra note 106, at 368 ("The most commonly heard justification for the doctrine of stare decisis rests on the need for certainty in the law.") ; see also Thomas v. Wash. Gas Light Co., 448 U.S. 261, 272 (1980):

The doctrine of stare decisis imposes a severe burden on the litigant who asks us to disavow one of our precedents. For that doctrine not only plays an important rule in orderly adjudication; it also serves the broader societal interests in evenhanded, consistent, and predictable application of legal rules. When rights have been created or modified in reliance on established rules of law, the arguments against their change have special force.

Id. (footnotes omitted); Manich v. S. S.S. Co., 321 U.S. 96, 113 (1944) (Frankfurter, J., dissenting) ("The tendency to disregard precedents... has become so strong in this Court of late as ... to shake confidence in the consistency of decision and leave courts below on an uncharted sea of doubt and difficulty without any confidence that what was said yesterday will hold good tomorrow ...."). 
predict with greater certainty the legality of various business practices and arrangements. ${ }^{194}$ The use of precedent also contributes to judicial economy by permitting judges to build on the work of those who came before them, rather than revisit each issue independently, and by reducing the need for litigation. ${ }^{195}$ Moreover, respect for precedent fosters respect for the judiciary. It requires consistency and improves decision making by requiring judges to draw on a body of law that represents the collective experience and knowledge of judges over time. ${ }^{196}$ As a result, stare decisis helps to reassure the public that the courts' decisions are not capricious, but are based instead on consistent and legitimate decision making. ${ }^{197}$ As Justice Cardozo noted, "[a]dherence to precedent must then be the rule rather than the exception if litigants are to have faith in the even-handed administration of justice in the courts." 198

A second argument for stare decisis rests on its intrinsic value. This argument is characterized by two separate claims. The first is that stare decisis is valuable for its own sake: The past has inherent authority over and a direct claim upon us. ${ }^{199}$ The second, and in my view stronger, version of

194. See WASSERSTROM, supra note 106, at 66-69 (discussing reliance justification for precedent); Lyons, supra note 193, at 496 (arguing that increased legal certainty decreases the risk of business transactions); Powell, su pra note 109, at 18 (indicating that consistency in court decisions "is especially important in cases involving property rights and commercial transactions").

195. See supra text accompanying notes 106-09 (discussing the impact of precedent on judicial workloads).

196. See Welch v. State Dep't of H ighways \& Pub. Transp., 483 U.S. 468, 479 ( 1987) (noting the importance of past Court wisdom on current controversies).

197. See Maltz, supra note 106, at 371 (arguing that an important aim of stare decisisto limit the policymaking powers of the courts); Powell, supra note 109, at 18 (arguing that public respect for the courts is due in part to the knowledge that courts are not composed of "unelected judges free to write their policy views into law").

198. CARDOZO, supra note 90 , at 34.

199. This set of arguments is often referred to as "traditionalism." As Dean Anthony T. Kronman wrote:

[F]or most of the time that human beings have lived together in organized communities, every aspect of their communal lives-social, religious, political, and economic as well as legal-has to a large degree been organized on the assumption that the past has an inherent authority of just this kind, a sanctity that obligates us to respect the patterns it prescribes. The name we give this once-pervasive attitude is traditionalism.

Anthony T. Kronman, Precedent and T radition, 99 YALE L.J. 1029, 1044 (1990). Arguments in this vein draw on the works of Georg Wilhelm Friedrich Hegel, seeH EGEL: THE ESSENTIAL WRITINGS (Frederick G. Weiss ed., 1974); Allan Bloom, AlLan BLoom, THE Closing of the American MIND (1987); Alasdair Maclntyre, ALASDAIR MaCINTYRE, AfTER VIRTUE: A STUdY IN M ORAL Theory (1981); Stanley Hauerwas, Why NarRative: PEAdings IN NARRATIVe Theology ( Stanley Hauerwas \& L. Gregory Jones eds., 1989); and especially Edmund Burke, EDMUND BuRKE, REFLECTIONS ON THE REVOLUTION IN FRANCE (1790), among others. Traditionalism is cast in opposition to the philosophical tradition exemplified by Hobbes, THOMAS HOBBES, LEVIATHAN 180-82 (Michael Oakeshott ed., 1962) (1651) (arguing that only the dictates of 
the intrinsic value argument is deontological: The use of precedent fosters justice because it encourages judges to treat like cases alike. ${ }^{200}$ This view implies that once a court has dealt with a situation, it is obligated to deal with similar situations in a similar way unless it finds adequate reason to treat them differently. The argument is based upon the belief that people have the right to be treated equally - to those in the past and future as well as to those in the present-and that, if two relevantly similar cases are treated differently, then one party has been treated unfairly. The deontological argument for precedent is thus simply a more specific form of a fundamental requirement of justice: Members of society in the same position should be treated equally. ${ }^{201}$ Viewed in this light, the doctrine of stare decisis is an appeal to a general principle of equality, a cousin of the Kantian principle of universalizability and the biblical Golden Rule. ${ }^{202}$

The insights that path dependence theory provides regarding the costs associated with stare decisis should not lead us to ignore the doctrine's many

reason deserve respect), and the work of Holmes, HOLMES, The Path of the Law, supra note 1 , at 187.

At the core of this argument, which has found its most recent and prominent advocate in Anthony Kronman, is the idea that humans live within a cultural tradition. This cultural tradition liberates human beings from the "narrow temporal constraints within which their ambitions would otherwise be confined, and permits them to dream and work on a scale larger than the limits of a single lifetime will permit." Kronman, supra, at 1052. But culture not only possesses the potential for accumulation, it is also highly vulnerable to destruction and ruin and therefore must be actively maintained in order to continue to exist. Id. at 1054. These characteristics are unique to culture, and culture is unique to humanity. Id. at 1064. The distinctiven ess of humanity, in other words, relies on our participation in the world of culture, which in turn owes its continuing existence to our respect for the work of past generations. Precedent, then, has a claim on us because the world of culture of which it is a part "makes us who we are." Id. at 1066. See also GRAY, NATURE AND SOURCES, supra note 89, at 198 ("[T] he weight attached to precedents in every department of life is closely connected with the force of habit, and has its roots deep in human nature ....").

200. See, e.g., H.L.A. HART, THE CONCEPT OF LAW 121 (1961) (arguing that this is the strongest rationale for the binding nature of precedent); WASSERSTROM, supra note 106, at 6972 (examining egalitarian justifications for precedent); Theodore M. Benditt, The Rule of Precedent, in PRECEDENT IN LAW 90 (Laurence Goldstein ed., 1987) ("Another argument for following precedent is that justice requires it. Like cases must be treated alike or else someone is being treated unfairly; therefore, decision makers must treat the parties in the instant case the same as parties in earlier cases were treated."); Karl Llewellyn, CaseL aw, in 3 ENCYCLOPEDIA OF THE SOCIAL SCIENCES 249 (1930) ("The force of precedent in the law is heightened by an additional factor: that curious, almost universal sense of justice which urges that all men are properly to be treated alike in like circumstances.") ; L yons, supra note 193, at 495 (arguing that "respect for precedent is required by the principle that like cases should be treated alike").

201. We achieve fairness by decision making rules designed to achieve consistency across a range of decisions. Where the consistency is amon g individual s at the same time, we express this decisional rule as "equality." Where the consistency among decisions takes place over time, we call our decisional rule "precedent." Equality and precedent are thus, respectively, the spatial and temporal branches of the same larger normative principle of consistency. Schauer, supra note 118 , at 596 .

202. Id. 
benefits. The theory of path dependence simply adds a new factor to the debate about when courts should obey or disobey precedent. The theory suggests that, ceteris paribus, the deference courts pay to precedent in a particular area of law should vary in direct proportion to the expected costs of path dependence. That is, courts should grant less deference to precedent when the costs of path dependence are likely to be high.

This response allows courts to check some of the costs engendered by the path dependence of the common law system. It does not, of course, provide an exact guide to when and how courts should treat different types of precedent differently. But it does identify a factor that courts should take into account as they determine the degree of deference to be granted to prior decisions. In some instances, this use of path dependence theory explains and justifies distinctions in the degree that judges rely upon precedent in certain categories of cases, thus providing a theoretical basis for existing practice. The theory also supports extending some existing distinctions in the degree of reliance upon precedent, as well as creating distinctions not already present in the common law. In these cases, path dependence theory provides an argument for modifying existing practices in specific ways.

In order to understand the proposal put forward here, it is important to observe the difference between a court's decision to apply a relaxed doctrine of stare decisis and its decision to follow or discard a particular precedent. A court may decide that it is appropriate to relax the doctrine of stare decisis, but nonetheless conclude that a particular precedent should be followed either because it is correct or because it is not clearly incorrect. Conversely, a court may decide that it should not relax the doctrine of stare decisis and yet conclude that a particular precedent should be discarded because it is clearly incorrect. Indeed, as al ready discussed, ${ }^{203}$ courts in the United States do not consider themselves inexorably bound by their own previous decisions. Path dependence theory does not provide any reason to alter this practice.

Finally, the proposal advocated here is not meant to capture all of the intricacies involved in determining when the doctrine of stare decisis should be closely observed and when it should not. Numerous factors may weigh in favor of or against the use of precedent in a particular case or class of cases. The argument I make here is simply that, all things being equal, when the costs of path dependence are high, courts should be more inclined to relax the doctrine of stare decisis. This conclusion necessarily ignores, for example, the other half of the cost-benefit calculus that can be applied to the doctrine of stare decisis. ${ }^{204}$

203. Sesupra note 90 and accompanying text (discussing how courts are not strictly bound by their own precedents).

204. The converse of my argument in this Article is that, where the benefits of stare decisis 
To illustrate the argument, I briefly examine three examples of categories of cases in which the costs of path dependence are expected to be relatively great and where, therefore, courts should be more willing, ceteris paribus, to relax the doctrine of stare decisis: cases in areas of the law in which there are few punctuations, cases that apply a legal rule developed under substantially different conditions, and cases that rely on dicta. ${ }^{205}$ Notably, courts already grant less deference to precedent in cases that fall within these categories. Thus the theory of path dependence provides theoretical support for existing court practices as well as modifications thereof.

\section{A. Casesin Areas of the LaW in Which There are Few Punctuations}

As described above, legal change is characterized by periods of stability punctuated by periods of rapid change. A legal rule gradually develops along a particular path until it is interrupted by the reversal of an earlier decision by a higher court or the enactment of a statute or a constitutional amendment. Such punctuations offer a brief opportunity for legal actors to realign legal arrangements that may gradually have grown out of sync with underlying societal conditions. Path dependence theory therefore predicts that, where punctuations occur more frequently, the system "self-corrects" more frequently. Consequently, the law moves in closer sync with societal conditions, assuming that the courts treat all types of precedent equally. By contrast, where punctuations occur less frequently, the law is expected to move further astray before such a correction occurs.

Nothing in the doctrine of stare decisis, however, requires that all forms of precedent receive identical treatment from the courts. Path dependence theory argues in favor of differential treatment of precedents in areas of law in which punctuations occur less frequently. When considering cases that fall into these areas of the law, the courts can ensure that the law does not grow too far out of alignment with societal conditions by more readily reconsidering principles established in prior decisions. Conversely, when considering cases that fall into areas of law in which punctuations occur more regularly, the courts can provide stability by showing greater deference to precedents.

Because much of path dependence theory captures existing intuitions, it should perhaps come as no surprise that current judicial practice already complies to a large extent with this prescription. Not all types of precedents

are greater, deference to precedent should be correspondingly greater. For example, one could argue that, where there is more reliance on a particular legal rule, the benefits of stare decisis are greater and thus deference should be correspondingly greater. This Article is not meant to preclude consideration of such benefits, which a complete theory of the proper application of stare decisis would have to take into account.

205. Of course, the three categories are not exclusive; a single case may fall within more than one. 
receive similar treatment from the courts. In particular, a clear distinction exists between the treatment of constitutional, statutory, and common law precedents. $^{206}$

Courts generally give less weight to precedent in the constitutional context, in which punctuations are infrequent. ${ }^{207}$ Indeed, there is no external check on judicial interpretations of constitutional provisions, save for constitutional amendments. Consequently, if courts proceed down a path of interpretation that grows increasingly undesirable, perhaps because of changing attitudes or changing conditions, courts are the only bodies that can easily modify that path.

A strong rule of stare decisis in the constitutional law area would lock courts, and therefore the country, into continued adherence to a precedent that may be clearly inappropriate. The observation that constitutional law is subject to few punctuations from forces outside the courts argues in favor of applying a somewhat more relaxed standard of stare decisis to constitutional precedents. Courts, in other words, should be prepared to correct a deviant path of law more often in the area of constitutional law than in a context in which the opportunities for change occur more frequently. ${ }^{208}$

By contrast, in the statutory context, courts consistently subject decisions to a much stronger standard of stare decisis because legislatures can provide a check on court decisions. ${ }^{209}$ If legislatures do not "approve" of

206. The following discussion owes a debt to William N. Eskridge, Jr.'s review of the emergence of these three standards of sare decisis. Se Eskridge, supra note 5, at 1364-69 (discussing the Supreme Court's practice of overruling statutory precedents). For more on the differential treatment of constitutional, statutory, and common law precedents, see Maltz, su pra note 106, at 388-93.

207. See Thomas v. Wash. Gas Light Co., 448 U.S. 261, 272 n.18 (1980) ("The doctrine of stare decisis has a more limited application when precedent rests on constitutional grounds, because "correction through legislative action is practically impossible.'") (quoting Burnet $v$. Coronado Oil \& Gas Co., 285 U.S. 393, 407 (1932) (Brandeis, J., dissenting) ); Mitchell v. W.T. Grant Co., 416 U.S. 600, 627 (1974) (Powell, J., concurring) (discussing the doctrine of stare decisis). In his dissent in Burnet, Justice Louis Brandeis defended the more relaxed standard of stare decisis that is generally ap plied to constitutional precedents in language that even reflects some of the insights of path dependence theory. Burnet, 285 U.S. at 405-08 (Brandeis, J., dissenting). He observed that "in most matters it is more important that the applicable rule of law be settled than that it be settled right. ... But in cases involving the Federal Constitution, where correction through legislative action is practically impossible, this Court has often overruled its prior decisions." I d. at 406-07, 407 n.2 (Brandeis, J., dissenting) (citing cases).

208. Path dependence theory thus adds a new dimension to the current debate over traditionalism in constitutional interpretation. Compare John Hart Ely, Foreword: On Discovering Fundamental Values, 92 H ARV. L. REV. 5, 39-43 (1978) (arguing that tradition is in tension with democracy), with Antonin Scalia, Common-Law Courts in a Civil-Law System: The Role of United States Federal Courts in Interpreting the Constitution and Laws, in A MATTER OF INTERPRETATION: FEDERAL COURTS AND THE LAW 3, 13 (Amy Gutmann ed., 1997) (arguing that the judiciary must not nnovate but should instead act to preserve consensuses reflected in longstanding tradition).

209. See, e.g., Francis v. S. Pac. Co., 333 U.S. 445, 450 (1948) (indicating that a longstanding interpretation of a statute becomes "part of the warp and woof of the legislation," which only 
a court's interpretation of a statute, they may change the operative language via legislation. ${ }^{210}$ Consequently, courts can rely on other actors to alter a path of statutory precedent that has grown undesirable-where undesirable

Congress can change); Erie R.R. v. Tompkins, 304 U.S. 64, 77-78 ( 1938) ("If only a question of statutory construction were involved, we should not be prepared to abandon a doctrine so widely applied throughout nearly a century. But the unconstitutionality of the course pursued has now been made clear and compels us to do so."); Douglass v. County of Pike, 101 U.S. 677, 687 (1880) ("After a statute has been settled by judicial construction, the construction becomes... as much a part of the statute as the text itself, and a change of a decision is ... the same in its effect ... as an amendment of the law by means of a legislative enactment."); see al so Frank C. Newman \& Stanley S. Surrey, Legislation: Cases and Materials 653 (1955) (indicating that judges are often particularly reluctant to overrule statutory precedents); N ote, The Power that Shall BeVested in a Precedent: Stare Decisis, the Constitution and the Supreme Court, 66 B.U. L. REV. 345, 369-70 (1986) (defending presumption of validity of statutory, but not constit utional, precedents).

William N. Eskridge, Jr. points out that the strict rule of stare decisis for statutory precedents is often abridged. He has identified three common exceptions to what he terms the "super strong presumption" for statutory precedents. He demonstrates that the Supreme Court has regularly overruled statutory precedent when it finds that the Court's consideration of the issue at hand was not thorough in the precedent (the "proceduralist exception"), where Congress has largely left development of the statutory scheme to the courts (the "exception for common law and constitutionalized statutes"), and where the precedent has not generated significant public or private reliance (the "reliance exception"). Eskridge, supra note 5, at 136884. Other scholars, focusing on different aspects of the Supreme Court's jurisprudence, posit somewhat different breakdowns in the rationale used by the Court for overruling precedent. For example, focusing on the Supreme Court's constitutional rather than statutory jurisprudence, one scholar notes that the Court will freely overrule when (1) "precedents conflict," (2) "conditions upon which the first decision was premised have changed," and (3) "the rules chosen by the Court have proved unworkable." Note, Constitutional Stare Decisis, 103 H ARV. L. REV. 1344, 1346 (1990) (footnotes omitted). As is clear on close examination, these exceptions again correspond fairly closely to the rules that would emerge from an application of path dependence theory.

210. Indeed, Justice H arlan Stone made just this argument in seeking to justify a strong rule of stare decisis for statutory precedents. He argued that, if Congress fails to amend a statute to overrule a statutory precedent or especially if it reenacts the statute without changing the relevant language, it signals its approval of the interpretation. Se, eg., Girouard v. United States, 328 U.S. 61, 70-76 (1946) (Stone, C.J., dissenting) (arguing that, where Court's statutory interpretation is publicized, Congress's failure to act to overrule it creates presumption that Congress approves); Apex Hosiery Co. v. Leader, 310 U.S. 469, $488-89$ (1940) (Stone, J.) ( refusing to revisit precedent in part because Congress had cle arly chosen not to intervene even though it was aware of the controversy). Indeed, the arguments for a stronger rule of precedent in the statutory context often rely upon the ability of the legislature to reverse erroneous interpretations of legislative intent. See III. Brick Co. v. Illinois, 431 U.S. 720, 736 ( 1977) (stating that the Supreme Court's earlier decision ought not be disturbed because it turned on a question of statutory construction which Congress could alter at any time); Boys M kts., Inc. v. Retail Clerks Union, Local 770, 398 U.S. 235, 240 (1970) (same). I do not mean to suggest, however, that legislatures can be expected to act whenever they do not approve of a decision of the courts relating to issues of statutory interpretation. Indeed, there are many reasons to believe that legislatures will frequently remain silent even in the face of a decision of which they do not approve. See Maltz, supra note 106, at 388-89 (arguing that the legislative correction rationale is overstated). The argument here simply relies on the fact that outside actors will intervene more frequently in the statutory context than in the constitutional one. 
precedent is defined as precedent that establishes a legal rule that diverges significantly from that which a rational, well-informed, and capable decisionmaker operating without the constraint of precedent would make. Courts are not the only possible source of punctuations in this context, and, hence, punctuations occur more easily and are more frequent. The courts thus bear less of the burden of correcting the path of the law and can err in the direction of protecting stability by deferring to precedent more readily than they might in the constitutional context.

Finally, courts typically treat common law precedents, which consist entirely of judge-made law and involve no statutory or constitutional principle to which the courts can look, as falling somewhere between the two poles of constitutional and statutory precedent. In the common law area, courts create the law in the absence of legislative or constitutional direction. As in the statutory context, legislatures may correct a path that it perceives as undesirable. H owever, legislatures are usually less likely to do so in the common law than in the statutory context because the area is, by definition, one that they have previously declined to enter. Thus, while another actor is able to alter the path taken by the courts, it is not likely to do so. That is, a punctuation may, but probably will not, come from outside the courts. In such circumstances, an intermediate presumption in favor of stare decisis is entirely reasonable.

Path dependence theory thus provides a theoretical basis for an existing practice. It justifies-and, indeed, argues for-differential treatment of constitutional, statutory, and common law precedents in an effort to balance the relative frequency with which punctuations occur in those areas of law. Seen in this light, the courts' more deferential treatment of statutory precedent and less deferential treatment of constitutional precedent reflect an effort to provide more stability when outside actors can be expected to reign in an errant legal rule, but take greater responsibility for the path of the law when outside actors are unlikely to intervene.

\section{B. Cases That Apply a Legal Rule DeVeloped Under Substantially DIFFERENT CONDITIONS}

Another category in which the costs of path dependence are likely to be high includes cases that apply a legal rule developed under substantially different conditions- where, that is, underlying conditions have changed markedly since the legal rule's introduction or where the original basis of the rule has since been revealed to be flawed. In these cases, path dependence theory argues in favor of greater relaxation of stare decisis, all other things being equal.

As has been discussed at length, path dependence theory suggests that stare decisis can lead to the maintenance of a legal principle that is outdated and inefficient. Over time, as a legal principle becomes more and more entrenched, its failure to respond to changes in underlying conditions can 
result in increasing inefficiency. For a variety of reasons, other actors may be ignorant of the growing inefficiency and therefore unlikely to act to change it. Alternatively, they may be aware of it but reluctant or unable to correct it. In such circumstances, path dependence theory would argue in favor of permitting the courts to relax the doctrine of stare decisis. ${ }^{211}$ The application of path dependence theory to the common law system thus leads to the conclusion that, ceteris paribus, the courts should reconsider staunch adherence to precedent when conditions have changed significantly, undermining the basis of the challenged precedent, or where the experience of time has made clear -in a way that it could not have been at the time the decision was made-that the precedent was "wrong" from the start.

The string of cases involving preemption of state statutes and common law by the Employment Retirement Income Security Act of 1974 (ERISA) illustrates the costs that may result from adherence to stare decisis when underlying conditions change. ${ }^{212}$ ERISA's preemption clause provides that state laws that "relate to" employee benefit plans shall be "superseded" by the Act unless the laws are preserved by one of the savings provisions of Section 514(b) of the Act. ${ }^{213}$ The first case presented to the Supreme Court regarding this clause involved the regulation of pension plans, which were the main focus of the Act. ${ }^{214}$ In this context, the Court interpreted ERISA's ambiguous preemption language to permit employee benefit plan sponsors to evade state regulation by self-insuring, rather than purchasing insurance. This approach was not problematic in the pension area because ERISA comprehensively regulates pension plans, filling the gap left by the preempted state regulations. $^{215}$

211. This proposal is similar to Eskridge's proposed commonsense "evolutive" approach to statutory precedent. Under the evolutive approach, a statutory precedent is more likely to be overruled if its reasoning has been exposed as problematic and its results pernicious, and it has not induced significant public and private reliance. See Eskridge, supra note 5, at 1385 (outlining the evolutive approach). The approach counsels the Court to consider three issues when it decides whether to reconsider a precedent: (1) With the benefit of hindsight, was the precedent wrongly decided? (2) Is it pernicious, detracting from national policies? (3) Do these problems outweigh the costs imposed on those who have acted in reliance on the decision? Id. at 1388. These three inquiries are designed to determine the extent to which the precedent has become obsolete.

212. I am indebted to Jacob H acker for suggesting this example.

213. 29 U.S.C. § 1144(a) (1988).

214. See Alessi v. RaybestosManhattan, Inc., 451 U.S. 504, 524-25 (1981) (holding that ERISA preempted a New Jersey workers' compensation law prohibiting pension plan provisions that deducted workers' compensation benefits from pension benefits and deciding that ERISA preemption is broader than ordinary federal preemption, which displaces only laws inconsistent with provisions or goals of federal law or in areas that federal law regulates).

215. See Catherine L. Fisk, The Last Article A bout the Language of ERISA Premption?: A Case Study of the Failure of Textualism, 33 HARV. J. ON LEGIS. 35, 68-69 (1996) (noting that the Supreme Court rejected two limits on preemption). 
O ver time, however, the Court's broad interpretation of the preemption language had the apparently unintended effect of creating regulatory voids in areas not substantively addressed in any depth by ERISA. ${ }^{216}$ This was perhaps most pronounced in the area of health finance. In response to the distinction created by the Court between insured and self-insured health plans, increasing numbers of employers self-insured to take advantage of ERISA's preemption of state regulation. ${ }^{217}$ This, in turn, led to a "significant but unintended shift in the structuring and financing of health plans $\mathrm{s}^{1218}$ and created a regulatory void in the area of health insurance. This occurred because, although ERISA preempts state laws on the topic, it does not provide any regulation in their place. ${ }^{219}$ At the same time, more stringent cost control practices by health plans gave rise to more frequent, intense, and consequential legal conflicts between medical insurers and patients seeking care. ${ }^{220}$ The conditions underlying the original decision thus have changed substantially since the Court first interpreted the ERISA preemption language, leading to a result unintended by the Court or by the Act's authors. ${ }^{221}$ Moreover, the legislature has proven unable or unwilling to respond to the problem because such a large constellation of private interests-most notably private health insurance companies-have arisen around the existing system. ${ }^{222}$ In such circumstances, I argue, it is appropriate for the courts to elax the doctrine of stare decisis and to reconsider the issue with a more critical eye toward precedents leading further down a path that began under entirely different circumstances.

The claim that changes in underlying conditions should cause courts to reconsider prior precedent is, of course, by no means entirely new. Even

216. Indeed, employers have even relied on the Court's interpretation of ERISA to challenge state laws that simply mention ERISA plans. Id. at 65-66.

217. Sœ id . at 67-68 (discussing the state insurance law exception ).

218. Id. at 68.

219. Cases involving ERISA preemption of state health regulations include Shaw v. Delta Air L ines, Inc., 463 U.S. 85 (1983) (finding that ERISA preempted state disability and human rights laws that prohibited discrimination on the grounds of pregnancy and required employers to provide sick leave to employees disabled by pregnancy); and Arcudi v. Stone \& Webster Engineering Corp., 463 U.S. 1220 (1983) (affirming summarily a case invalidating a state statute that required employers to continue health, accident, and life insurance coverage for their employees while they received workers' compensation benefits).

220. See Robert Pear, H ands Tied, Judges Rue L aw that Limits H .M .O. Liability, N.Y. TIMES, July 11,1998 , at A1.

221. Congress intended to encourage employers to provide benefits to workers by establishing uniform federal standards for pension and health plans so that insurers would not have to comply with a multitude of conflicting state laws and regulations. Id.

222. This, of course, suggests that lock-in in the legal system is not just a result of stare decisis, but of lock-in effects in the lawmaking process as well. Se Pierson, Increasing Returns, supra note 14, at 37-47 (describing the path dependence of the policymaking process). An interesting avenue of future research would be to examine the interplay between the path dependent processes in the three political branches. 
Justice Cardozo, a staunch advocate of the doctrine of stare decisis, conceded that "when a rule, after it has been duly tested by experience, has been found to be inconsistent with the sense of justice or with the social welfare, there should be less hesitation in frank avowal and full abandonment." $223 \mathrm{He}$ went on to advocate that "[t]here should be greater readiness to abandon an untenable position... particularly when in its origin it was the product of institutions or conditions which have gained a new significance or development with the progress of the years."224 Similarly, the Supreme Court has acknowledged that changes in underlying conditions can lead a court to reconsider the validity of a prior precedent. In Planned Parenthood v. Casey, ${ }^{225}$ for example, the Court explained that in determining whether to overrule a prior case, courts consider "whether facts have so changed, or come to be seen so differently, as to have robbed the old rule of significant application or justification." 226

Of course, the simple observation that courts should be more willing to relax the doctrine of stare decisis when underlying conditions have changed begs the difficult question of what types of changes qualify. As with any legal rule, the prescription is not absolute: Judges must use discretion when putting rules into effect. But path dependence theory can provide some specific guidance in answering the question of when judges should apply a relaxed standard. It suggests that, before applying a relaxed standard of stare decisis, judges should identify some clear, relevant, underlying changes that have undermined the precedent. The changes must undermine the central basis of the original decision. Changes in peripheral or minor details are not sufficient. Indeed, if the conditions underlying the central basis for the original precedent remain unchanged, and a judge simply disagrees with a decision, the judge should nonetheless follow the precedent-unless, of course, there is another basis in law for doing otherwise. ${ }^{227}$

223. CARDOZO, supra note 90 , at 150 .

224. Id. at 151. He also noted that:

"That court best serves the law which recognizes that the rules which grew up in a remote generation may, in the fullness of experience, be found to serve another generation badly, and which discards the old rule when it finds that another rule of law represents what should be according to the established an settled judgment of society, and no considerable property rights have become vested in reliance upon the old rule."

Id. at 151 (citation omitted).

225. 505 U.S. 833 ( 1992).

226. Id. at 855 .

227. As noted above, the doctrine of stare decisis does not bind a court to follow its own precedent where it finds it to be fundamentally incorrect. Thus, a judge may apply the doctrine of stare decisis and yet come to the conclusion that a decision is wrong and must be reversed. I do not intend to imply here that this practice should be changed in any way. Rather, I simply mean to argue that the theory of path dependence supports a relaxation of the doctrine of stare decisis only in certain specific circumstances. 
Path dependence theory thus lends a theoretical underpinning to a pragmatic consideration applied occasionally by the courts. ${ }^{228}$ In fact, it not only provides a rationale for an occasional practice, but it also argues for a more systematic and regular application of the practice. Moreover, it provides more specific guidance for when courts should and should not base a decision to relax the doctrine of stare decisis on changes in social conditions by requiring a focus on the centrality of those changes to the basisfor the original decision.

\section{CASES THAT RELY ON DICTA}

A third category of cases in which the costs of stare decisis are high are cases that rely on dicta-statements unnecessary to the decision in a preceding case. As I have argued, because of the nonergodicity of the American common law system, small, early statements can have large effects over time. ${ }^{229}$ When those statements are not well considered or address issues that have not been thoroughly briefed, the chances increase that the nonergodicity of the common l aw will lead to negative effects..$^{230}$

Two conclusions can be drawn from this observation. The first is that courts should be reluctant to defer to dicta in previous decisions. To some extent, of course, this recommendation reflects current practice. Courts often refuse to rely on previous decisions cited for propositions made in dicta. However, the admonition to avoid reliance on dicta is also frequently broken. Courts regularly cite propositions in prior decisions that are of questionable importance to the earlier decisions. The observation that such practices introduce significant costs encourages greater reluctance to rely on such statements. As Roscoe Pound once observed,

It is not stare decisis that the law reformer should be assailing.... What needs rectification is a judicial habit of following language extracted from its setting by text writers, of adherence to formulas instead of to the principle of decisions, and the taking of the words for law rather than the judicial action which those words sought to explain. ${ }^{231}$

A second conclusion is that judges should not write opinions that stray from their central issues. This supports a practice that might be termed judicial restraint or judicial minimalism: a policy of deciding only those

228. See Casey, 505 U.S. at 854 ("[W]hen this Court reexamines a prior holding, its judgment is customarily informed by a series of prudential and pragmatic considerations designed to test the consistency of overruling a prior decision with the ideal of the rule of law, and to gauge the respective costs of reaffirming and overruling a prior case.").

229. Sesupra text accompanying notes 121-26.

230. It is, of course, possible that there will be dicta that is both well-briefed and wellconsidered. This argument does not apply with the same force in such circumstances.

231. Pound, supra note 5, at 13. 
issues that are central to the instant case and avoiding issues that are not. ${ }^{232}$ Including extraneous statements in an opinion invites later reliance on those statements and thus multiplies the costs of a nonergodic common law system. If a judge writes an opinion that decides issues or includes statements that are not directly relevant to the issues raised in the case, those statements may or may not be carefully examined by other members of the court and therefore pose a higher risk of error. Moreover, the statements may later form the basis for rulings by the same or a lower court on the issue unnecessarily addressed, thus multiplying the impact of an original error. In this way, possibly ill-considered statements may gain greater influence over time. For this reason, judges should be discouraged from intentionally or unintentionally storing "nuts to be pulled out at some later time." 233

The theory of path dependence thus provides support for stricter adherence to an existing principle of law: Courts should rely only on those statements in previous opinions that are necessary to the decision and should avoid reliance on dicta. Moreover, it argues in favor of the somewhat more controversial practice of judicial minimalism, in the sense that it counsels judges to include in an opinion no more than what is necessary to decide the case at hand thoroughly and completely.

\section{CONCLUSION}

The doctrine of stare decisis that is central to our common law system creates an explicitly path-dependent process. The past forms the point of departure for the present. The present, in turn, forms the point of departure for the future. Therefore, the historical path leading to each new outcome or decision directly shapes that outcome in specific and systematic ways. Oliver Wendell Holmes was thus correct when he said that understanding the history of the law is central to understanding the law as it is today.

By applying the three strands of path dependence drawn from the social and natural sciences, we learn a great deal about the specific ways in which history shapes and constrains the legal process. We learn that small early events have a significant impact on outcomes, the doctrine of stare

232. The judicial minimalism supported by path dependence theory is subtly different from the judicial minimalism advocated by Cass Sunstein. Se CASS R. SUnSTEIn, O NE CASE AT A TIME: JUdiCIAL MINIMALISM ON THE SUPREME COURT 4 (1999) (arguing in favor of "saying no more than necessary to justify an outcome, and leaving as much as possible undecided"). The judicial minimalism advocated here, by contrast, entails not straying in an opinion from issues that are central to the case. This does not necessarily require leaving as much as possible undecided; rather, it simply requires not including statements that are extraneous to the issue presented. In other words, while Sunstein's minimalism argues against statements that are central to the issue at hand but that may have a broader impact than on the specific issue presented, the minimalism argued for here would permit such statements as long as they are directly relevant to the issue presented.

233. MURPHY, supra note 121, at 203. 
decisis locks in legal rules, and outcomes are difficult to predict. In addition, we better understand that legal rules evolve gradually over time but that this gradual evolution is regularly punctuated by significant shifts in the legal environment. These opportunities for significant change are brief and intermittent, and the new arrangements that emerge out of them significantly shape and constrain future developments in the law. Furthermore, we now understand that the order in which cases are presented to the courts can have a significant impact on the legal rules that emerge. Finally, we understand that path dependence can lead to growing inefficiency over time, as rules are unable to change with the underlying social conditions that they govern.

Applying path dependence theory to the law thus provides new insights into the course and pattern of legal change in a common law system. It builds upon the work of scholars who have long observed the parallels between evolution in nature and evolution in the law, while offering a corrective to the evolution-to-efficiency claims that have dominated this scholarship in recent decades. ${ }^{234}$ Moreover, the theory of path dependence expands the focus of historical inquiry beyond the evolutionary model by identifying three separate accounts of how history influences the pattern and process of legal change in a common law system-increasing returns, evolutionary, and sequencing path dependence. And it describes the specific features of the legal system that are likely to bring about and reinforce these forms of path dependence, thus linking legal institutions and legal outcomes. In the process, it helps scholars and practitioners to understand better the sources of legal stability and change and thereby to identify, and even create, opportunities for significant al terations in the law. ${ }^{235}$

The descriptive insights provided by path dependence theory also have normative implications. The observation that a system of law that relies upon

234. Path dependence theory demonstrates that legal outcomes are shaped not only by the facts and issues presented in the courtroom but also by the history of the courts' consideration of similar cases. Consequently, the legal rules applied may not al ways be the very best, or most efficient, that could be constructed were courts uncon strained by history. Legal equivalents of the imperfect panda's thumb or the inefficient Q werty keyboard-evidence of the rule's path of development-remain throughout the legal system.

235. Another important consequence - and a worthy avenue of future research-is that common law legal systems will likely demonstrate characteristics not found in civil law systems, which do not recognize the existence of a formal doctrine of stare decisis. This can help explain some variation in legal rules between nations with dfferent legal systems. Of course, to the extent that civil law systems rely primarily on national codes, they will still exhibit path depen dence insofar as the legislative process that produces the codes is itself influenced by path dependence. Se sources cited supra note 45 (providing overview of literature applying path dependence theory to various political processes). The path dependence will simply be of a different form. Moreover, path dependence theory suggests that international variation in legal rules can be explained, at least in part, by looking to variations between countries in small early events and the types of and opportunities for punctuations, which play such an important role in the evolution of legal rules. 
precedent is path dependent and that path dependence can lead to certain identifiable costs, including inefficient legal rules and dependence of outcomes on the order in which cases are presented, requires us to reexamine once again the long-accepted doctrine of stare decisis upon which our common law system rests. The remaining challenge is to determine when the newly defined costs of path dependence in the common law system are sufficiently significant to justify relaxing the doctrine of stare decisis. If we succeed, we will be left with a legal regime that preserves the value of stare decisis while responding to the changing historical currents of the complex world it governs. 